Portland State University

PDXScholar

1973

\title{
An Investigation of Vocational Rehabilitation Among Northwest Laryngectomees
}

Susan L. Leonti

Portland State University

Follow this and additional works at: https://pdxscholar.library.pdx.edu/open_access_etds

Part of the Speech and Hearing Science Commons, and the Speech Pathology and Audiology Commons

Let us know how access to this document benefits you.

\section{Recommended Citation}

Leonti, Susan L., "An Investigation of Vocational Rehabilitation Among Northwest Laryngectomees" (1973). Dissertations and Theses. Paper 2049.

https://doi.org/10.15760/etd.2048

This Thesis is brought to you for free and open access. It has been accepted for inclusion in Dissertations and Theses by an authorized administrator of PDXScholar. Please contact us if we can make this document more accessible: pdxscholar@pdx.edu. 
AN ABSPRACT OT THE IHASTS OP Susew I. Leorti ros the Megter of Science in Speech, with emphasis in Speech Patrology/ Audiology presented April 19, 1973.

Title: An Investigation of Vocational Renabinitation Anong Northwest Laryngeotomees.

APPROVPD BY MENBERS OF THE THESIS COMMTMT:

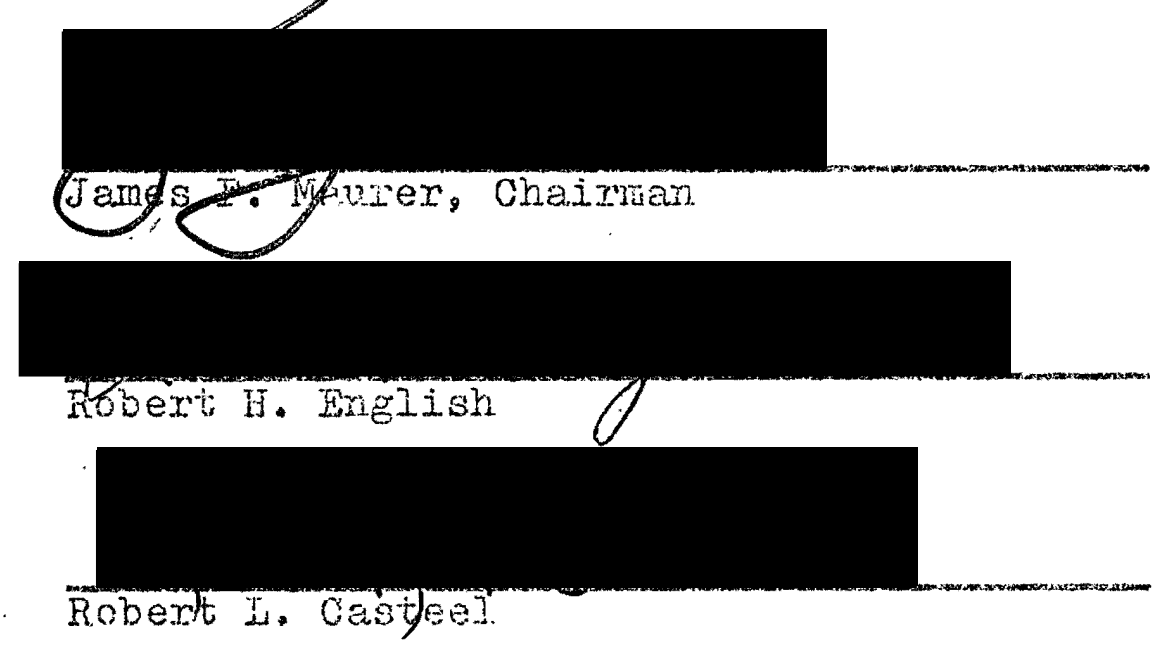

Rehabilitation for patients recorering from surgzical removal of the laxyn should include vocational considerations with accompanying economic modificetions. The literam ture pertaining to rehabilitative menagement of laryngen. tomees revealed numerous investigations concerned with physical restoration, remedial speech trairing and paychom social adjustment, whils few studies here been condupted concentrating upon rocational consequences of a laryngectomy. The primary purpose of this investigation was to 
examine the pre- and post-operative vocational status of laryngectomized patients residing in the Noxthwestern section is the Uaitea Status.

The sample was composed of 210 laryngectornees whose names were suppliea by the Oregon Division or the American Cancer society. In addition, a restricted population was surveyed consisting of spouses, relatives, or close friends cf the patient who chose to participate in trie study.

Iwo questionnaires were formulated as a means of collecting data. Part I was completed by the laryngectomee and part II by the spouse, relative, ox close friend. The forms asked a variety of questions involving age, pre- and post-operative employment, financial status, psycho-social adjustment, and method of commication.

Roplies were received from 117 patients end 76 spouses or relatives. Following systematic analysis of the extensire data obtained, five answerable questions were generated limiting the study to a suxvey of rocational rehabilitation of laryngectomees. Reiated information concerning psychosocjal and cormunicative factors were inoluded when applim cable.

Significant resuits of this study are sumarized as follows:

1. No specific pre-operative oecupational category appeared to typify this sample.

2. Enployment inmediately following convalescence 
was common for the laryngectomees.

3. The number of retired laryngectomees doubled. following surgery.

4. Desire for employment was shown to be the nost motivating factor in learning esophageal speech.

5. Esophageal speech was used by a large portion of the laryngectomized sample.

6. Wile most spouses reported minimal changes in life style following surgery, a significant number indicated marital problems, financial difficulties, and/or emotional maladjustment. 


\title{
AT INVESTIGATION OR VOCATIONAL REHABIIITATTON AMONG NORWHWEST IARYNGECTOMETS
}

\author{
by \\ SUSAN L. LEGITI
}

A thesis submitted in partial fulfillment of the requirements for the degree of

\author{
MASTER OF SCIBNOS \\ in \\ SPEECI \\ With emphasis in \\ Speech Pathology \\ and Audiology
}

Portuland State Unirexsity

1973 


\section{ACKN OWLEDGIVENIS}

I would like to take this opportunity to express my sincere appreciation to Dr. James F. Maurer, Thesis Chairman, for his support, inspiration, guidance and unfailing good humor. Thanks also to my thesis cominitee members, Drs. Robert H. English and Robert I. Casteel, for their guiding comments.

Special gratitude to Philip S. King, M.D., Director, Research and Education in PM\&R, Veterans Administration Hospital, Portland, Oregon; Ms. Betty Cary, President, New Voice Club of the Northwest; and Mr. Donald Schwain, Direc-. tor, Oregon Diviaion of Vocational Rehabilitation, for their constant encouragement, interest and thoughtful suggestions.

My warmest regerds to members of the llew Voice Club of the Northwest who so enthusiastically participated in this study. Nay they all have a happy, healthy, and "verbal" iuture.

To my fanily and friends-thanks for being so patient and trusting that one day I will actually finish! 
TO THE OFHICE OF GRADUATE STUDIES AND RESEARCH:

The members of the Committee approve the thesis of Susan I. Leonti presented April 19, 1973.

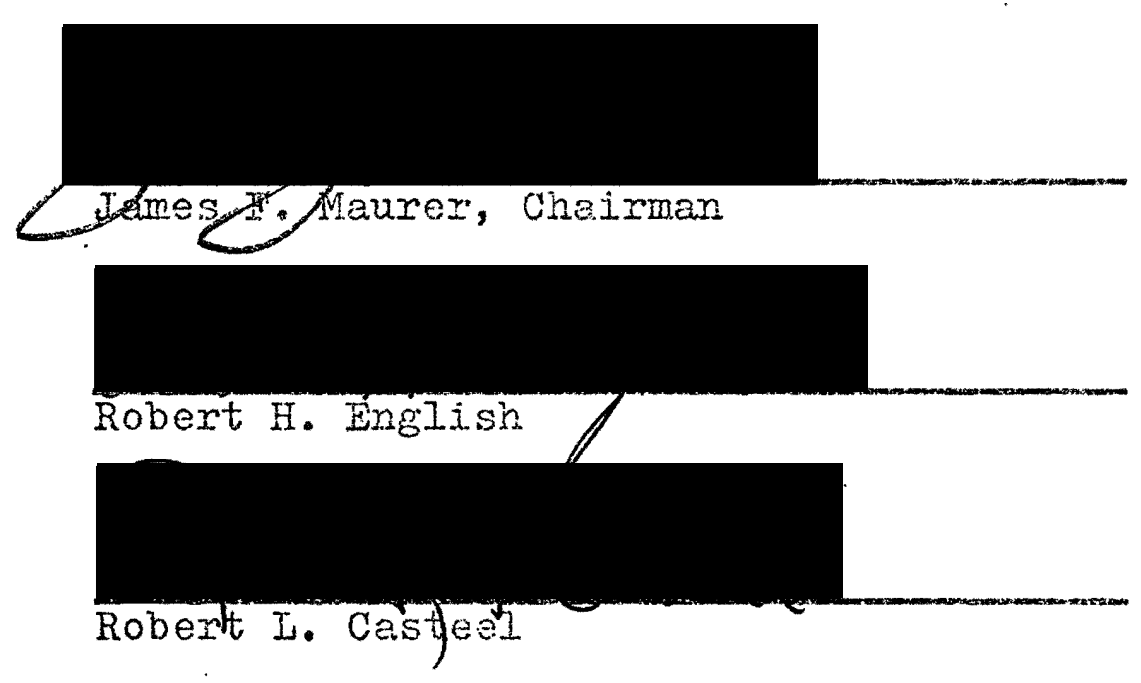

APPROVPD:

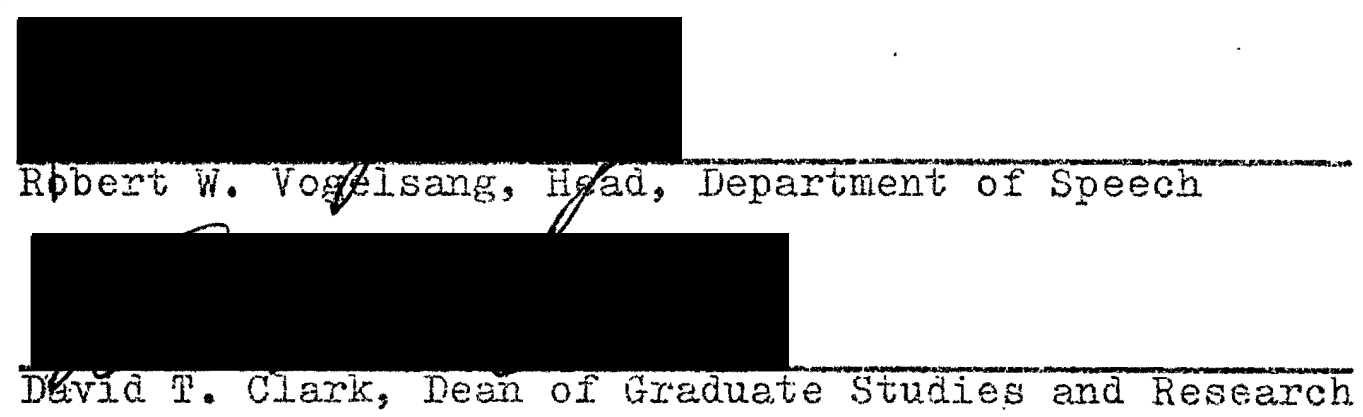

April 23, 1973 
PABLE OF CONTENTS

PAGE

ACTHONIEDGRENTS . . . . . . . . . . . . i . ii

IIST OI TABLES. . . . . . . . . . . . . . v vi

IIST CF FIGURES . . . . . . . . . . . . . vii

CHAPTER

I REVIEW OF IITERATURE AND STATEWENT OF

PROBLEM . . . . . . . . . . . . . 1

Introduction. .......... 1

Review of the Iiterature. . . . . 2

Statement of the Problem. . . . . 8

II SUBJECTS, MRTHODS, AND PROCEDURES . . . . 10

subjects. . . . . . . . . 10

Methoàs .......... . 10

Procedures. . . . . . . . . 11

III RESUITS AND DISCUSSTON. • • • • . • . 12

Pre-Operative Occupations . . . . 13

Percentage of Patients Remaining in

Pre-operative occupations . . . . 15

Post-Operative Occupations. . . . . 25

Motjvating ractors in Learning ssopha-

geal Speech . . . . . . . 28 
Pinancial and Social Corisequences on the family ........... 32

IV SUIMTARY AND CONCIUSIONS . . . . . .

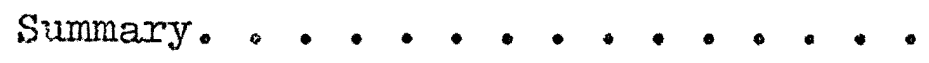

Conclusions. . . . . . . .

Implications of the Study...... 42

Rehabilitation

Need for Inture Research

BIBLIOGRAPHY. . . . . . . . . . . . .

APPENDICES

APPENDIX A: COVER IETTER

QUESTIONNAIRES PART I AND II. . .

48

APPENDIX B: PREOPERATIVE OCCUPATIONS . . .

61

APPENDIX C: POST-OPERATIVE OCCUPATIONS. . . 


\section{IISE OP TABIES}

TABLE

I Number and Percentage Distribution of PreOperative Occupational Categories . . .

II Number and Percentage Distribution of

Reasons for Not Returning to Pre.-

Operative Occupations . . . . . . .

II Number and Percentage Distribution of

Patients' Present Communication Status.

IV Number and Percentage Distribution of PostOperative Occupational Categories . .

$r$ Number and Percentage' Distribution of

Factors Motivating Patient to Jearn

to Speak . . . . . . . . . . .

VI Number and Percentage Distribution of

Patients Indicatjng Variance in Annual

Income Following Surgery . . . . .

VII Number and Percentage Distribution of

Spouses Indicating Major Changes in

Irife Style . . . . . . . . . ... 


\section{IEST OR FIGURES}

FIGURE

1. Number and Pexcentage Distribution of

Patients Remaining in Pre-Operative

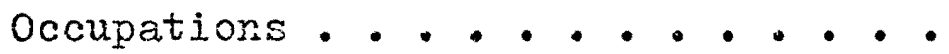

2. Number and Percentage Distribution of

Patients Retained in Exact Position.

3. Number and Percentage Distribution of

Patients Required to Speak and have

Contact with the Public.......

4. Number and Percentage Distribution of

Patients Reporting Employer's Atti-

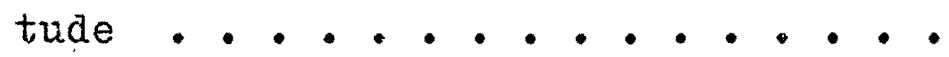

5. Number and Percentage Distribution of

Patient's Response to Employer

Eucation . . . . . . . . . .

6. Number and Percentage Distribution of

Patients: Own Attitude Poward Job. .

7. Number and Fercentage Distribution of

Patients Not Returning to Their Pre-

Operative Occupations . . . . . .

8. Number and Percentage Distribution of

Patients Indicating Whose Decision 
Not to Return to Work ........

9. Iumber and Percentage Distribution of

Patients Indicating Attitude Toward

Post-operative Occupational Change. .

10. Number and Percentage Distribution of

Patients Indicating IAI Membership

Helpea Them Return to Their Job

Routine . . . . . . . . . .

11. Number and Percentage Distribution of

Patients Indicating Which Factor

Produced the Greatest Financial Stress

as a Result of Surgery. . . . . . 


\section{CHAPTER I}

REVIEW OF IITERATURE AND STATEMENT OF PROBLEM

\section{Introduction}

The concept of rehabilitation for patients recovering from surgical removal of the larynx has changed radically in recent years. Traditionally, management was restricted to physical restoration of the patient with incidental attention directed toward associated environmental influences such as family, job and commurication. presently, cinicians recognize that successful rehabilitation for laryngectomees involves not only the patient's adaptation to anatomical and physiological alternations, but also skill in acquiring an intelifible mode of communication and ability to recover from possible psycho-social trauma. Also, specielists are currently extending rehabilitation to include vocational considerations with accompanying economic modifications.

Incidence figures indicate that the number of patients surviving from surgery has increased steadily over the last two decades. Estimates by the imerican Cancer Sodiety show that the population of laxyngectomees in the united states currentily numbers 25,000, and approximately 4,000 new cases are reported annualiy (Diedrich and Ioungstrom, 1966, p. 1). 
As a consequence, more patients require the services of trained rehabilitation specialists.

Most researchers convend that Laryngectomes are capable of functioning as productive nembers of society. Acceptance of this philosophy entails exploration of all modalities of the rehabilitative process: physical, commuricative, psycho-social and rocational.

\section{Review of the Iiterature}

A review of the literature pertaining to the renabilitation of laryngectomized patients revealed numerous studies concerned with anatomical and physiological restoration (Jimison, 1957; Holinger et al., 1957; Fitkin, 1953; Gardnen, 1961; Boone, 1971; Diedrich and Youngstrom, 1966; Snidecor, 1969; Horn, 1962; King et $31 . ., 1968$; and others), psychosocial adjustment (Nurphy, Bisno, and Ogura, 1964; Greene, 1947; Gardner, 1961; Gardner, 1966; Jevin, 1966; Locke, 1966; Nahum et al.; 1963; Sto11, 1958; Pitkin, 1953; and Reed, 1961), and communicative trainirg (Boone, 1971; Snidecor, 1969; Diedrich and Youngstrom, 1966; Heaver and Arnold, 1962; Oreech, 1966; Monlenaax-Bija, 1953; Nartin, 1955; and Waldrop and Gould, 1956), while few studjes have been conducted concentrating upon rocational corsequences of a laryngectomy.

Need for vocational research becomes paramount since the litersture suggests that 90 to $95 \%$ of laryngectomees 
axe men (King et al., 1968; Greene, 1947; Baker, 1965; Boone, 1971; Snidecor, 1969; and Diedrich and Youngstrom, 1966). The mean age of surgery has been found to be betweert 50 and 60 years (Boone, 1971; King, 1968; Snidecox, 1969; Harrington, 1960; Johnson, Barton, and Percello, 1961), an age at which most men are physically capable of employment and normally the major financial supporter of a family. Thus, data conceming economic implications of a laryngectomy is vital.

Pitkin (1953) states that return to work is obviously dependent upon many factors including the patienc's will and need to work, type of job held prior to surgery, his philosophical outlook, communicative ability and emotional adjustment. Results of his study of 62 laryngectomees revealed that among those patients eligible for employment, haif of the patients questioned (31) were engaged in the same occupan tions as prior to surgery. Eleven patients were working but not at the same pre-operative job. In most cases, the change of job had been necessitated by speech difficulties or inability to speak.

Murphy et al. (1964) investigated vocational and social factors following total laryngectomy. The sample consisted of 60 private patients seen by one of the authors between April 24, 1956, and April 24, 1960. By April, 1962, twentyone were known to be deceased or to have experienced reoccurrence of cancer. Of the thirty-eight living cancer-free 
patients, twenty-four were interviewed. Fourteen patients were inaccessible due to geographical distance thus information was obtained by letters. The interview consisted of questions about education, pre- and post-operative employment, marital history, psychiatric history, and postoperative voice and adjustment problems.

The following results were obtained concerning the pre- and post-operative employment of the twenty-four patients interviewed: twenty-three of the twenty-four: patients were regularly employed immediately prior to surgery; one patient had been retired for several years as a result of a head injury; sixteen patients resumed their previous occupations after surgery; and one patient resumed work at one of two part-time jobs held prior to surgery. Six patients faijed to returm to work.

The Murphy study concluded that in attempting to find pre-operative predictors of post-operative adjustment, cormparisons were made with those who did and those who did not resume regular employment, with respect to such factors as patient's age, education, employment history, maxital stability, overindulfence in alcohol, and estimated importance of voice in the patient's usual occupation. "No factor or group of factors proved to be predictive of rehabilitation" (Murphy et al., 1964, p. 541).

Gardner (1964) studied the vocational rehabilitation of laryngectomees. The gurpose of his study was to present 
results of two preliminary surveys of members of Lost Chord Clubs concerning problems faced in returning to work. Garaner fornd that "persons in all occupations are subject to cancer of the larynx" (Gardner, 1964, p. 777).

Questionnaires were sent to all laryngectomees in the Lost Chord Club of Cleveland. Replies were received from 115 laryngectomees. Eight patients (7\%) were more than 65 years of age at the time of the operation. One hundred-seven patients (93\%) were operated upon at an age customarily acceptable for continuation of employment. Eighty-two (72\%) returmed to their previous jobs. Nine changed jobs, but seven of these were retained in the same company and the other two obtained jobs elsewhere.

Gardner ( $p .781$ ) presents data concerning employer's reasons for change of jobs as reported by the laryngectomees: poor speech $(N=10)$, endangering of health and safety of the laryngectomee himself or fellow employee $(\mathrm{N}=11)$, both causes $(N=5)$.

Eighty percent of the eighty w-two patients who retained their jobs had fair to good esophageal speech and twenty percent had poor or no speech. Two-thirds of the thirtythree patients who changed or lost jobs had fair to good speech and one-third had poor or no speech.

In a later study, Gardner (1966, p. 36) investigated problems of laryngectorized women. He found that, $58 \%$ of the married and $50 \%$ of the single women, who 
had worked before surgery, returned to their same job after surgery. The return to work was closely related to the ability of the patients to regain speech.

Ranney (1965) surveyed the employment status of 1,299 IAI (Intermational Association of Laryngectomees) members of 32 clubs following surgery. He found that $76 \%$ retained their original jobs after convalescence and that $24 \%$ (one out of five) were without a job following surgery. Specifically, Ranney, (p. 1) found:

of this group of 258 , the largest portion were released from their jobs by their employers. The 192 who were fired represents $17.66 \%$ of those working at the time of their surgery; 24 (4.33\%) were demoted and $19(1.75 \%)$ resigned voluntarily.

Results of the Horm (1962) study of 3,366 laryngectomees offers interesting information on occupational changes or loss of employment following surgery: the greatest job and economic changes, which usually were in the direction of lower income levels, occurred in managerial, sales, clerical, skilled-labor, and semi-skilled labor occupations. Professional and unskilied-labor occupations reported little change in status. Horn also found that the percentage of those who were retired doubled from $12 \%$ before the operation to $24 \%$ after, and the percentage of those unemployed rose from $2 \%$ before to $8 \%$ following surgery. Gardnex (1964), King et al. (1968), and Greene (1947) claim that to a considerable extent reemployment depends upon regaining effective communication. Gardner and King found that more laryngectomees with intelligible speech 
were retained in previous occupations. Specifically, King et 2l. (1968, p. 200) stated that in this stuajy of veterans:

- . half of the eligible patients who were able to communicate by esophageal speech alone had some form of employrnent, while none of those without esophageal speech were employed.

King (1970) suggests that approximately $70 \%$ of laryngectomees are physically capable of returning to their. previous jobs and certainly a higher percentage are capable of returning to some modified form of employment. Allowance must be made for those with other physical problems such as heart disease or severe emphysema which are not uncommon diseases of these patients. Alcoholism also may be considered a significant factor. King (1970) estimates that 25 to $50 \%$ of laryngectomees are known to overindulge in alcohol.

Most investigators have found that a high percentage of patients are employed following surgery. Greene (1947), reports data indicating $70 \%$, Gardner (1964) $79 \%$, and Hunt (1964), 94\%, while King et al. (1968) found that only 5\% of the veterans surveyed at a Veterans Administration Hospital had full time employment and $22 \%$ indicated some form of part-time employment. All of the patients of this latter investigation had some form of pension ox compensation.

The Irtemational Association of Iaryngectomees published a pamphlet with the eim of infoming employers about the reemployability of laryngectomees. The pamplet supports 
a positive approach toward vocational rehabilitation:

"There is no reason, in most cases, why your laryngectomized exiloyee should not continue on the job" (IAI, 1966, p. 2). The IAI contends that there are only a few jobs that perhaps laryngectomees are unable to handle, specifically, those with an environment of extreme heat, cold, gases, dusts, and fumes. However, even in these adverse environments, with adequate protection of the stoma, Iaryngectomees are frequently capable of optimally performing modified vocational skills.

\section{Statement of the Problem}

The previously cited investigations on the rocational status of laryngectomees were conducted either over a wide, non-specific geographical area and/or limited to the Fasterm portion of the United States. The present study was designed to survey the pre- and post-operative occupational statis of laryngectomees residing in the Northwestern section of the United states. In addition, this study investigated several related areas which previous researchers failed to explore.

It is felt that such a study would have regional implications on the rehabilitatjve care and vocational. status of a population not previously surveyed.

This study seeks to answer the following five questions concerning Northwest laryngectomees:

1. What Specific Occupations Did the Laryngectomees 
Hold Prior to Laryngeal Surgery?

2. What Percentage of Patients Remained in Thejr Pre-Operative Oecupations?

3. What Post-Operative Occupational Changes Were Reported?

4. Was Employment a Primary Motivating Factor in Iearning Esophageal Speech?

5. Were There Any Financial Changes or Other Social Consequences on the Family of the Laryngectomized Patient? 


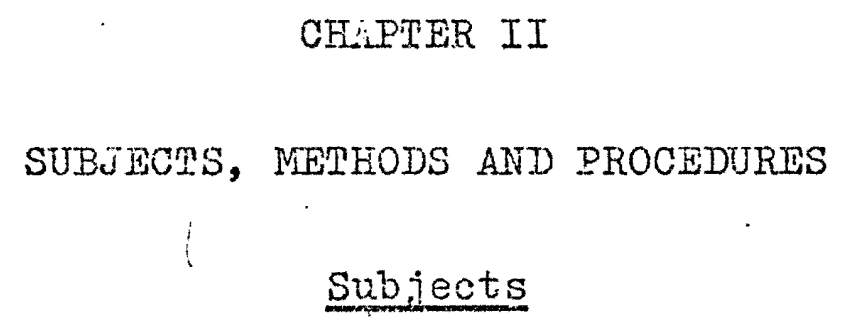

The population upon which this analysis was based con sisted of a total sample of 210 laryngectomees residing primarily in the state of Oregon, with a few subjects from Washington, Northern California, Idaho, Alaska, and Montana, who were identified by the Oregon Division of the American Cancer society. In addition, the next of kin o: each merner of the laryngectomized sample was queried for familial responses in a separate questionnaire.

\section{Methods}

Questionnaires were constructed as a means of collecting data (See Appendix A). The questionnaires consisted of two parts. Part I, to be completed by the laryngectomee, involved categoxies such as pre- and post-operative vocationa]. status, communicative ability, and level of education. Questions concerning psycho-social odjustment were restricted to present marital status and social participation. The construction of Part I was predominately limited to the altermate-chojce, closed form presentation; howerer, due to the nature of some items, it was necessary to include 
six open formed questions. Part I consisted of a total of 21 questions inciuding sub-categories ranging from 1 to 5 responses.

Part II, to be completed by the patient's spouse, relative, or close friend, irrolved an assessment of the patient's familial adjustment, relationship with the spouse, reactions of the spouse to surgery, and the concomittant influence of comnuicative skills on vocational status.

\section{Procedures}

The questionnaires (Parts I and II), an introductory letter, and an enelosed business reply envelope, were mailed. to the subjects in 1970. Recipients of questionnaire Part I distributed questionnaire Part II to the appropriate spcuse, relative, or close friend.

The data revealed by the questionnaires was examined and summarized in terms of recational status, communicative ability, and psycho-social influences. The frequency distribution of subject responses was calculated and categormized according to percentages, rounded to the nearest whole number. 


\section{RESULTS AND DISCUSSION}

One hundred-seventeen, 56 percent of the sample of laryngectomees surveyed, responded to Questionnaire Part I. rifteen (15\%) of these respondents were female and 84 (85\%) were male. Eighteen subjects did not indicate their sex. Ages ranged from 40 years to over 80 years with a mean age of 65 years. Ninety-three $(44 \%)$ did not respond; six (3\%) were reported to be deceased at the time of this study.

The questionnaires completed by the laxyngectomees revealed the following information pertaining to educational level: the largest percentage, $31 \%(\mathrm{~N}=32)$ stated they had completed elementary schooling and/or below; $24 \%$ $(N=28)$ high school training; 15\% (N=15) were high sohool graduates; $1 \%(N=1)$ completed sorne form of vocationaI training; $19 \%(N=19)$ had some college training; $6 \%(N=6)$ were college graduates; and $1 \%(N=1)$ bad completed some graduate work.

In Part II sarpling, which included next of kin, of the 76 responding, 63 (83\%) were wives, 5 (7\%) were husbands, $5(7 \%)$ were daughters, and $3(4 \%)$ were sons. Ithe number of next of kin respondents was inordinately çepressed by the fact that 20 laryngectomees $(17 \%)$ indicated they lived alone. 
An analysis of the data on Part I directed toward laryngectomees revealed answers to the five questions posited in the statement of the probiem:

1. What Specific Occupations Did the Laryngectomees Hold Prior to Iaryngeal Surgery?

Table I shows a summary of the pre-operative occupaTABLE I

NUMBER AND PERCENTAGE DISTRIBUTION OF PREOPERATIVE OCCUPATIONAI CATEGORIES

\begin{tabular}{|c|c|c|c|}
\hline Category Number ard Name & Number & Percentage & $\begin{array}{c}\text { Total } \\
\text { Number } \\
\text { Responding }\end{array}$ \\
\hline $\begin{array}{l}\text { 1. Professional, Tech- } \\
\text { nical and Managerial }\end{array}$ & 16 & 15 & \\
\hline $\begin{array}{l}\text { 2. Clerical and Sales } \\
\text { Occupations }\end{array}$ & 9 & 8 & \\
\hline 3. Service Occupations & 8 & 7 & \\
\hline $\begin{array}{l}\text { 4. Farming, Fishexy, } \\
\text { Forestry and Related }\end{array}$ & 4 & 4 & \\
\hline $\begin{array}{l}\text { 5. Processing occupam } \\
\text { tjons }\end{array}$ & 3 & 3 & \\
\hline $\begin{array}{l}\text { 6. Machine-Praces occum } \\
\text { pations }\end{array}$ & 5 & 5 & \\
\hline $\begin{array}{l}\text { 7. Bench Work occupa- } \\
\text { tions }\end{array}$ & 2 & 2 & \\
\hline $\begin{array}{l}\text { 8. Structural Work Cccu- } \\
\text { pations }\end{array}$ & 11 & 10 & \\
\hline $\begin{array}{l}\text { 9. Miscelloneous occu- } \\
\text { pations }\end{array}$ & 17 & 16 & . \\
\hline 10. Housewite & 5 & 5 & \\
\hline 11. Unemployed & i & 1 & \\
\hline 12. Retired & 26 & 24 & 107 \\
\hline
\end{tabular}


tional status of the sample of Northwest laryngectomees. Most pre-operative occupations reported by the subjects were classified according to the 9 categories designated by the U.S. Department of Labor in the Djctionary of occupational Titles: Definitions and Titles, W. Willard Wirtz, (ed.), (1965); three aditional categories (10, 11, and 12) were specified for the purposes of this study to account for those patients whose occupations could not be conveniently determined by the other 9 categories (See Appendix B). An analysis of categories 1-9 revealed that the largest (16\%) occupational category was \#9, "Miscellaneous Occupations." This category included occupations such as truck drivers $(N=16)$, loggers $(N=5)$, a longshoreman $(N=1)$, railroad laborers $(N=4)$, and an individual engaged in the automobile business $(N=1)$. The second largest category (15\%) was \#1, "Professional, Technical, and Managerial," which included an accountant $(N=1)$, postmaster $(N=1)$, teacher of pritrate music lessons $(N=1)$, engineers $(\mathbb{N}=3)$, supervisors $(N=3)$, managers $(N=3)$, and a $U . S$. immigration officer $(\mathrm{N}=1)$. Category \#7, "Bench Work," comprised the smaliest ( $2 \%$ ) class. In addition, the data indicated that of the remaining three categories, $24 \%$ were retired at the time of surgery, $5 \%$ were housewives, and $1 \%$ were unemployed.

Ihis study showed that there was no one specific occupationk job that contributed significantly more 
laryngectomees than another. The largest number of laryngectomees were from miscellaneous occupations (Category 9) which consisted of skilled and semi-skilled laborers. The second highest was Professional, Technical, and Managerial (Category 1).

2. What Percentage of Patients Remained in their Pre-0perative Occupations?

Sixty-three percent $(N=89)$ of the present subjects returned to their previous employment following surgery (See Figure 1). This rate of employment return is slightly lower than in previously cited studies by Gardner (1964) who reports 79\%, Green (1947), 70\%, and Hunt (1964), 94\%.

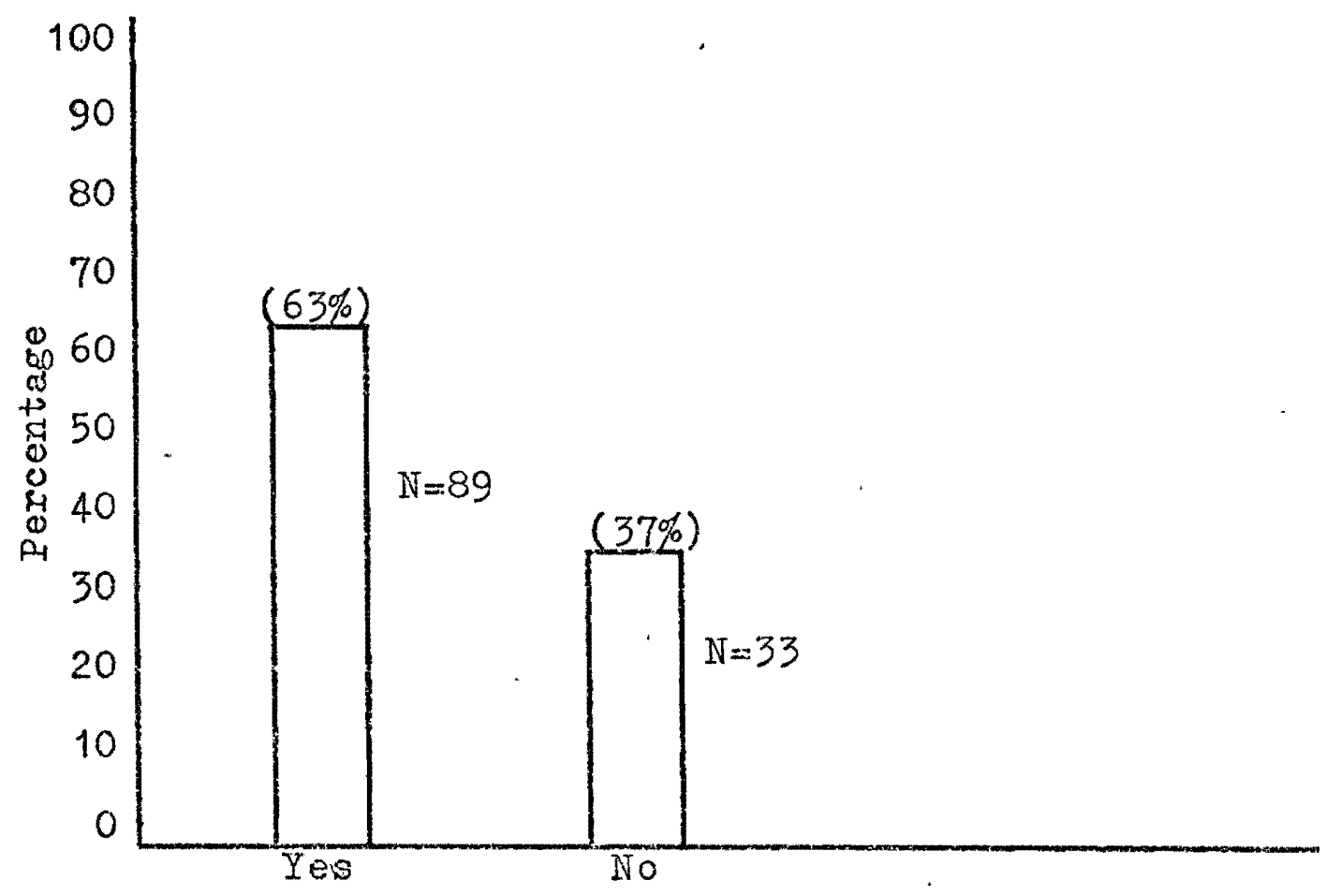

Figure 1. Number and percentage distribution of patients remaining in pre-operative occupations. 
How Many Patients Were Retained in Their Exact Occupational Positions?

An analysis of subsequent questions related to job retention revealed that $74 \%(N=37)$ of the subjects retained the same pre-operative position. Twenty-six percent $(N=13)$ reported that although they were retained in the same company, they did not return to their previous position (See Figure 2). Results of previous studies, (Ranney, 1965 and Gardner, 1964) found that 76\% (Ranney) and 72\% (Gardner) returned to their exact pre-operative occupational position. It can be seen that similarities exist between previous studies and the current study.

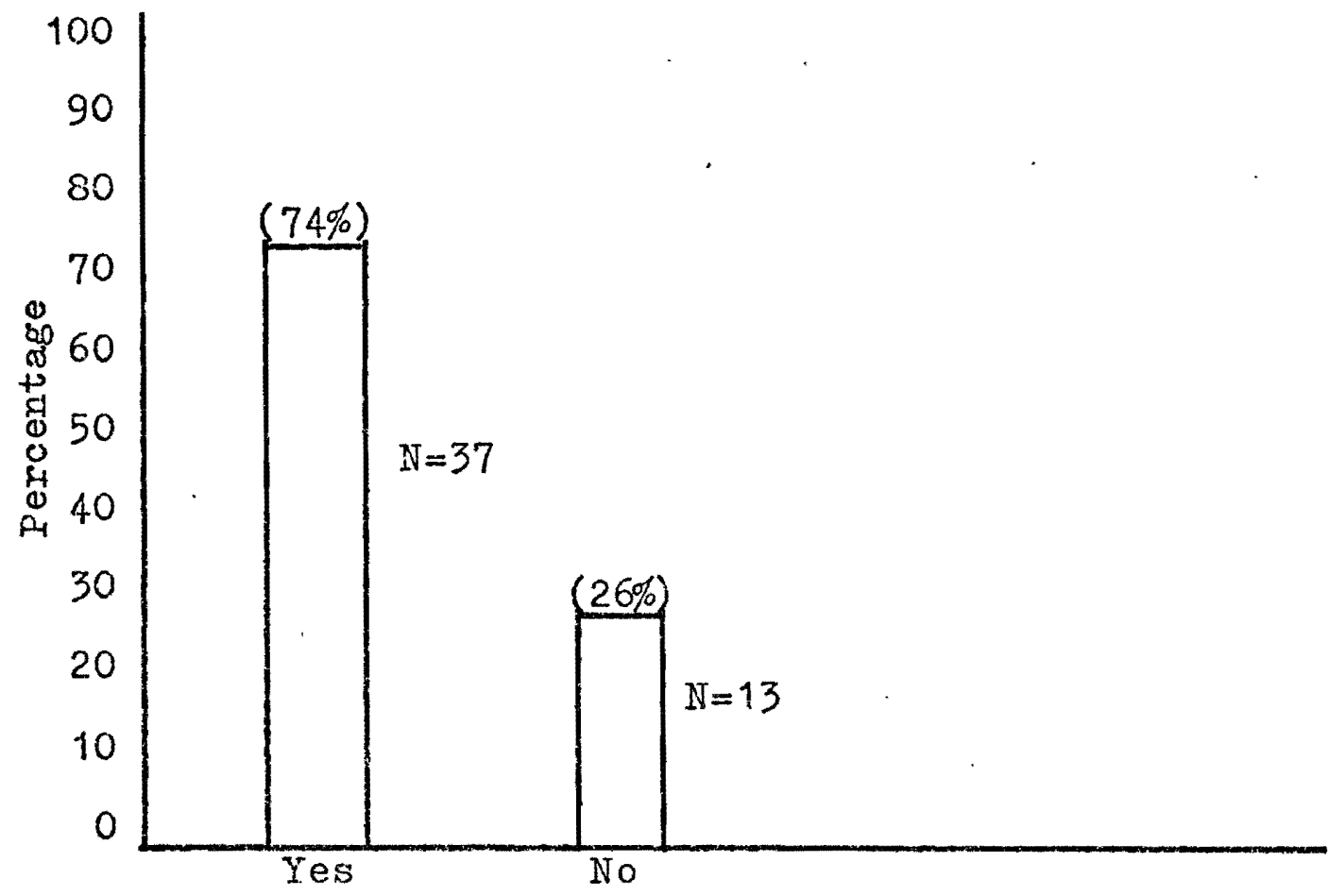

Figure 2. Number and percentage distribution of patients retained in exact position. 
Did the Dosition Require the Use of Speech and Contact with the Public?

Eighty-seven percent $(\mathbb{N}=41)$ indicated that their preoperative position required speaking and $80 \%(N=35)$ reported the job required direct contact with the public; $13 \%(N=6)$ reported that the position did not necessitate use of voice and $20 \%(N=9)$ indicated no public contact was related to the job (See Figure 3).

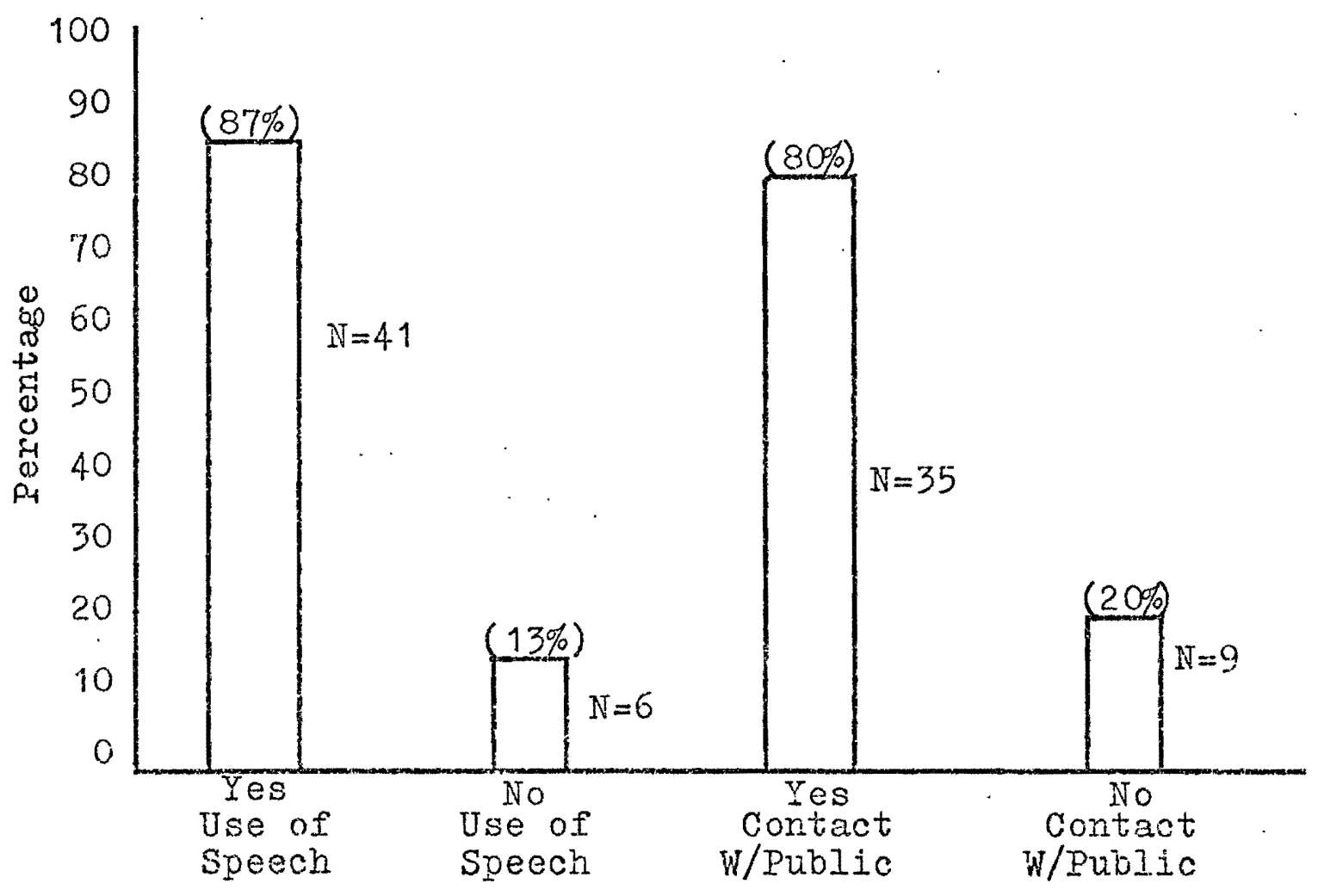

Tigure 3. Number and percentage distribution of patients required to speak and have contact with the public.

\section{Did Imployer's Attitudes Change?}

To the question "Did you notice a change in your employer's attitude toward you after surgery?" 12\% $(\mathrm{N}=5)$ 
reported a more favorable attitude, $12 \%(N=5)$ a less favorable attitude, and $76 \%(N=32)$ no change of attitude (See Figure 4).

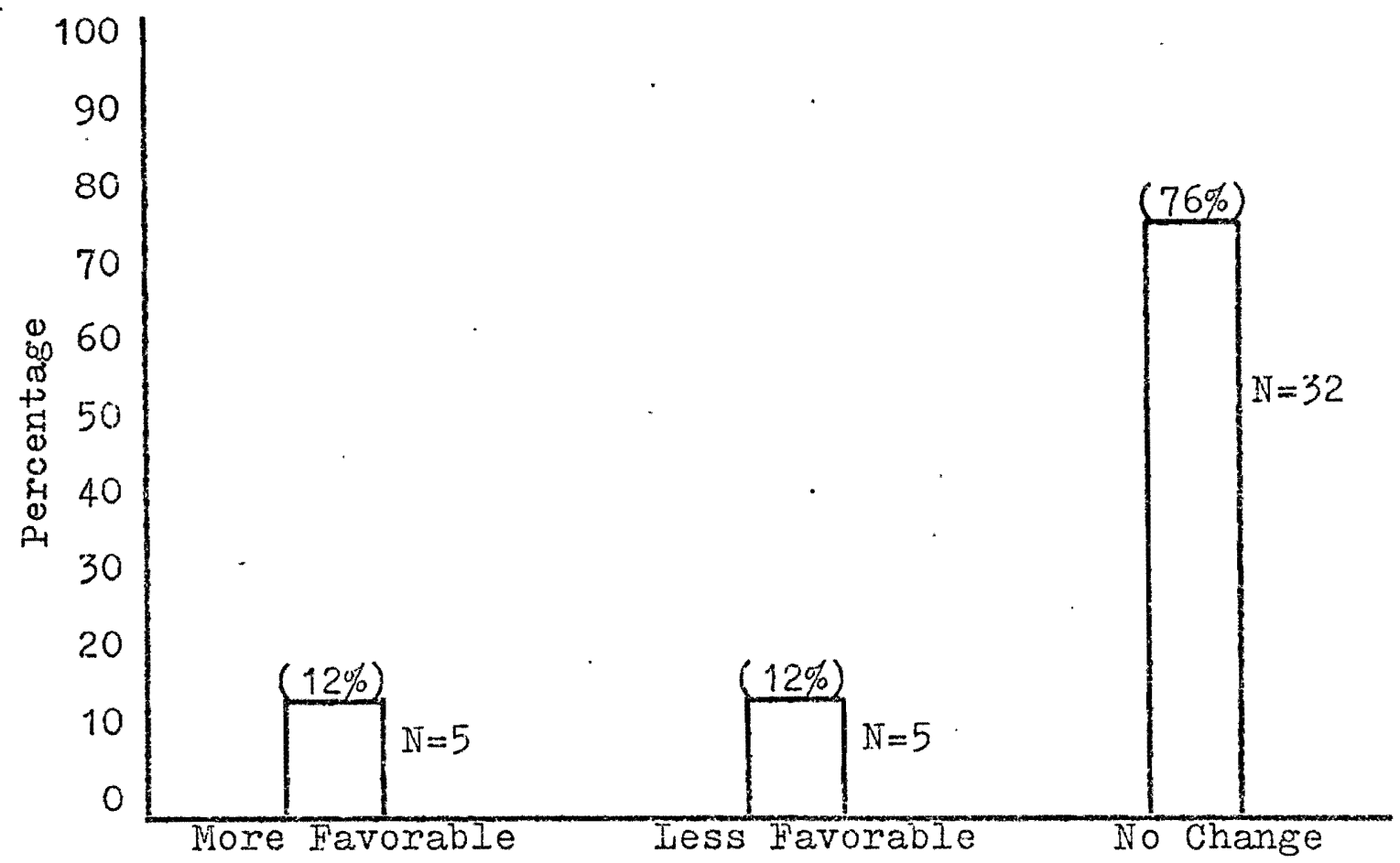

Figure 4. Number and percentage distribution of patients reporting employer's attitude.

Significantly, $75 \%(N=38)$ responded positively to the question, "Do you feel that your employer has been adequately informed of the nature and problems of the laryngectomized?" Even though a higher percentage responded "yes," there still remains 20\% (N=10) who responded "no" (See Figure 5). These data suggests an improvement in employer education since results reported by Garoiner (1964, p. 780) to a similar question, ("Do you think that employers should be better informed about proper methods of handing laryngectomized 
persons?"). At that time, "yes" was the answer of 76 of the 82 respondents who kept their jobs. It woula appear that currently laryngectomes feel that employers are now better informed and more sympathetic toward readjustment problems. It may be postulated that this improved employer attitude is due partially to education provided by local IAI Clubs plus information distributed by the ACS. Adaitionally, the time span of 8 years and the geographical location (Cleveland vs Northwest) could be considered as possible variables influencing this change.

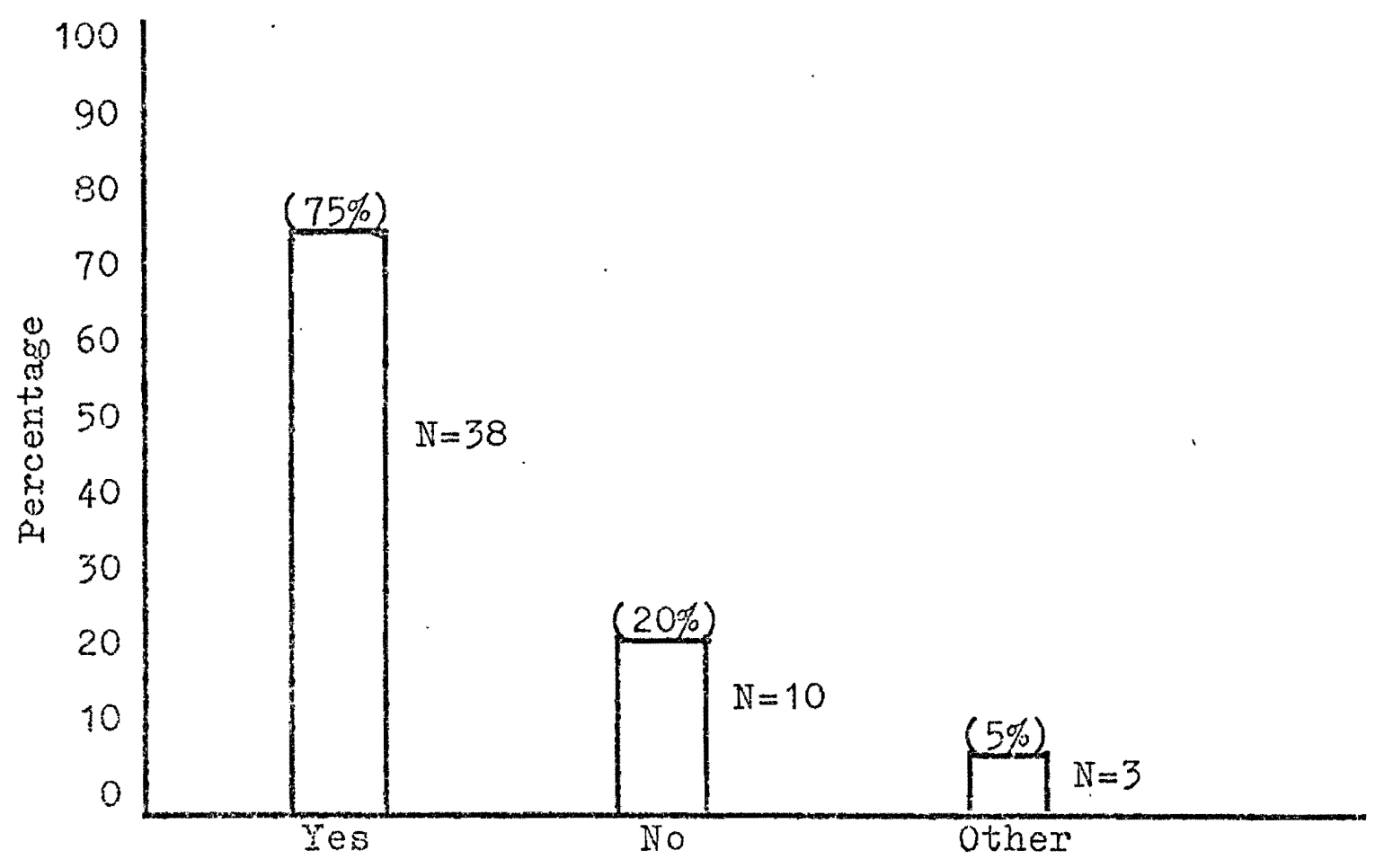

Figure 5. Number and percentage distribution of patient's response to employer education.

Did the Laryngectomees Notice

a Change of Attitude?

To the question, "Did you notice a change in your 
attitude toward your job after surgery?", 78\% (N-35) reported no change, $18 \%(N=8)$ less favorable change, and $4 \%(N=2)$ more favorable change (see Figure 6). The trend suggests that the largest percentage of patients held basically the same attitudes toward their pre-operative jobs.

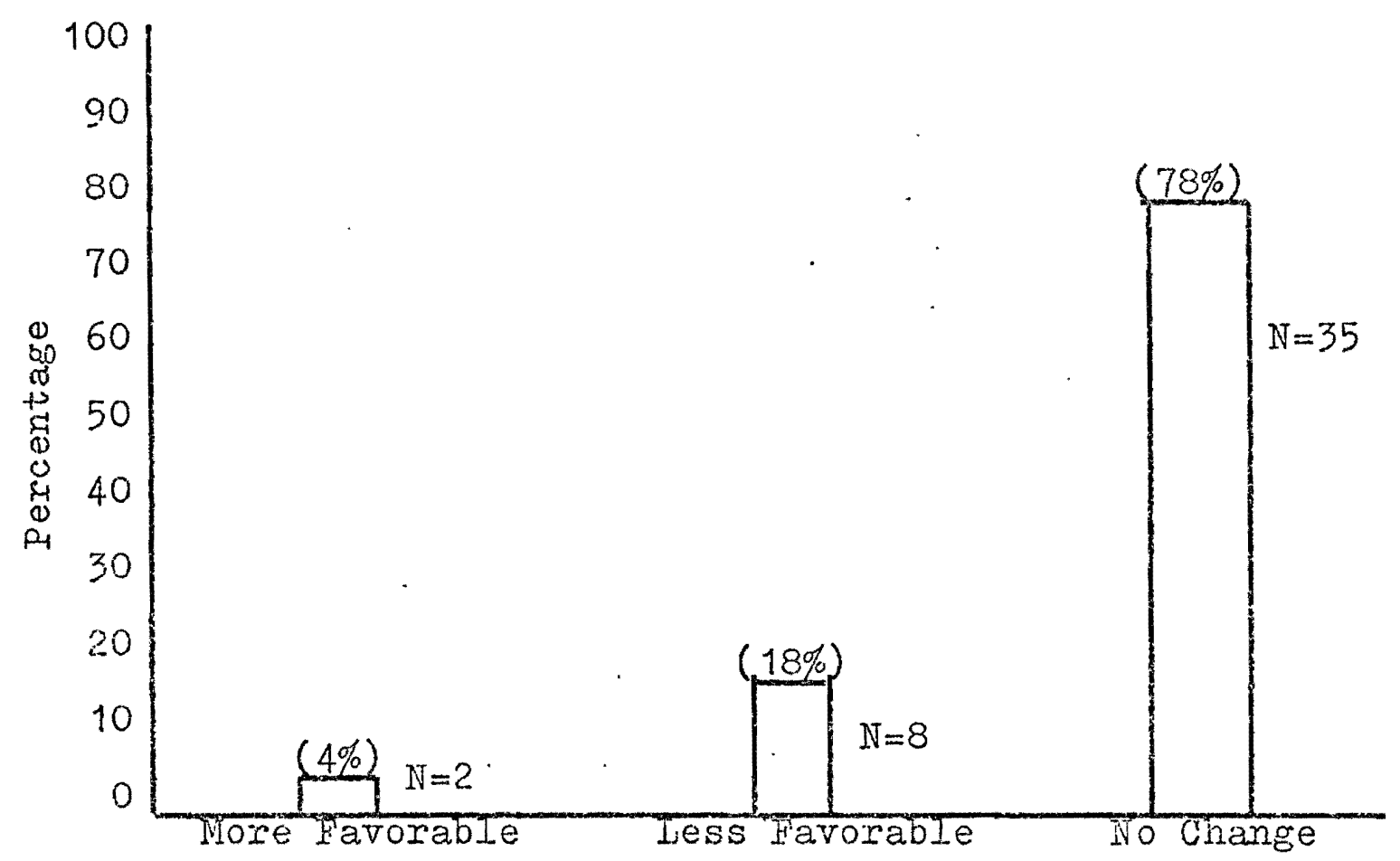

Figure 6. Number and percentage distribution of patients own attitude toward job.

How Many Patients Did Not Return to Their pre-operative Positions?

Thirty-three subjects (37\%) stated that they were not retained in their pre-operative occupations. Previously, Ranney (1965) reported that $24 \%$ (one out of five) of his sample of 1,229 IAF members of 32 clubs were without a job 
following surgexy. The present study indicates a slightly lower rate of employment return in this geographical area (See Fighre 7).

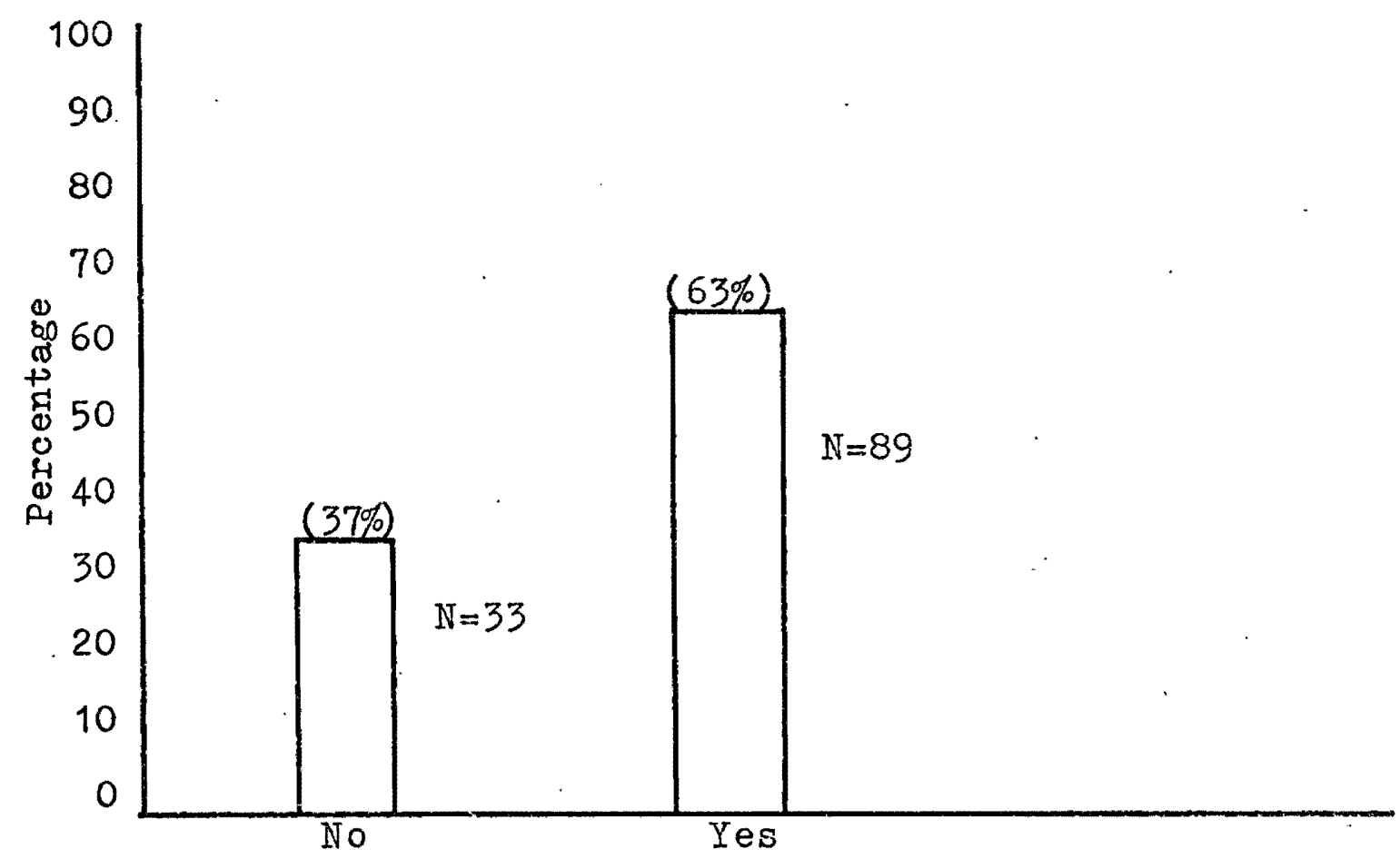

Figure 7. Number and percentage distribution of patients not returning to their pre-operative occupations.

Table II presents data concerning the current respondents reported reasons for not returning to pre-operative occupations. Table II shows that $28 \%(N=8)$ retired; $31 \%$ $(\mathrm{N}=9)$ attributed loss of speech as the majon reason for not returning to work; $28 \%(\mathrm{~N}=8)$ indicated disability and/or health factors; $7 \%(N=2)$ changed positions; 1 patient ( $3 \%)$ stated he was layed off; and 1 patient (3\%) reported other reasons not mentioned. Loss of speech was considered to be 
the most frequent factor influencing job dissolution closeiy followed by disability.

\section{TABIE II}

\section{NUMBER AND PERCENTAGE DISTRIBUTION OF \\ REASONS FOR NOT RETURNING TO PRE- \\ OPERATIVE OCCUPATIONS}

\begin{tabular}{|l|c|c|c|}
\hline Stated Reason & Notal & $\begin{array}{c}\text { Number } \\
\text { Number }\end{array}$ & Percent \\
Responding
\end{tabular}

In an earlier study of similar nature, Gardner (1964,

p. 781) offered information concerning employer's reasons for change of jobs as reported by laryngectomees: poor speech $(\mathbb{N}=10)$, endangering of health and safety of the laryngectomee himself or fellow employee $(N=11)$, both causes $(N=5)$.

Was It the Employer's or Patien't's Decision Not to Return to Work?

Sixty-seven percent $(N=18)$ reported that j.t was their personal decision not to return to work, $7 \%(N=2)$ stated it 
was theix employer's decision, and $26 \%$ ( $N=7$ ) both (See Figure 8).

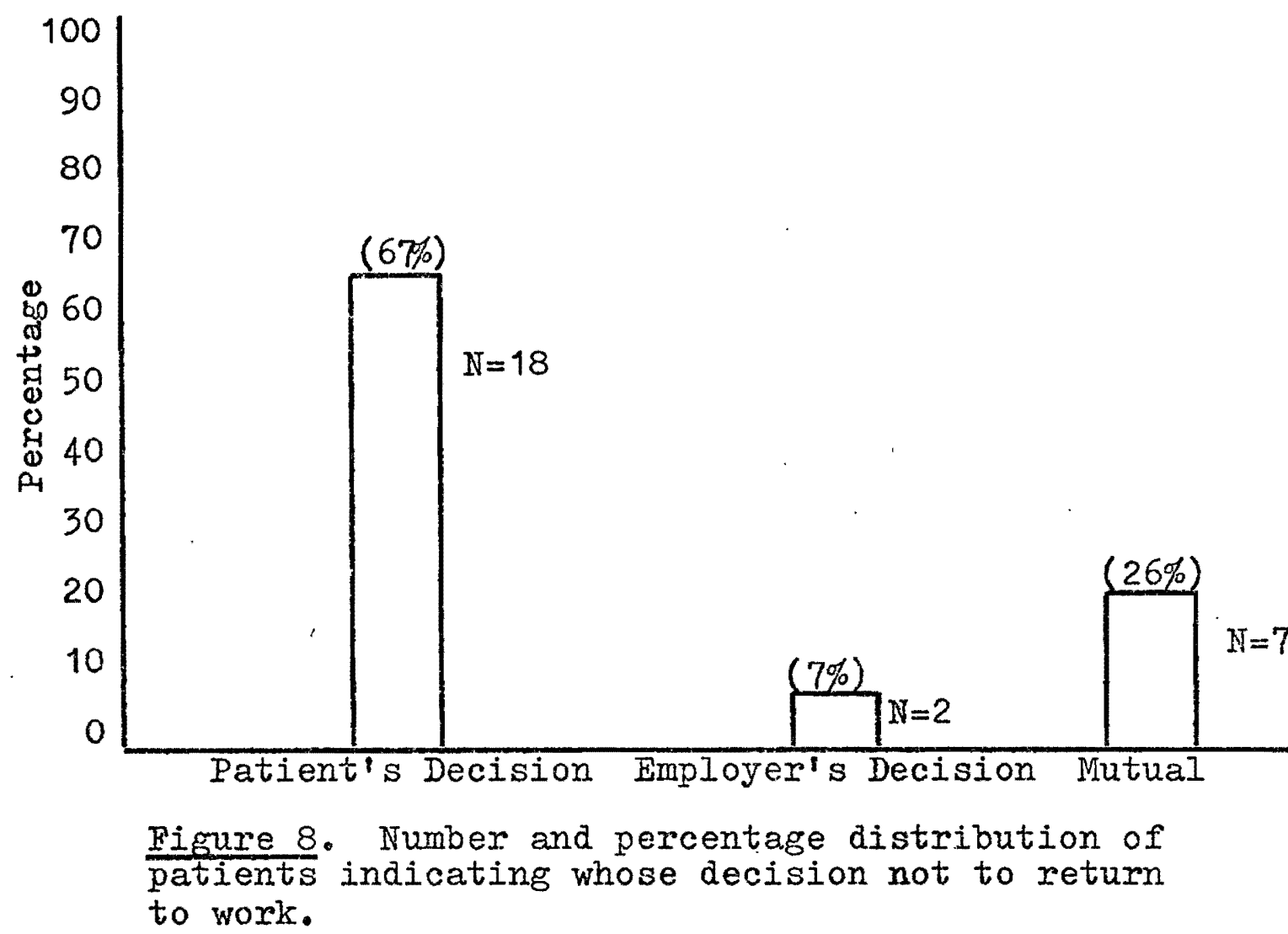

Does Communicative Ability Affect Job Retention?

Gardner (1964), King et al. (1968), and Greene (1947) claim that to a considerable extent re-employment depends upon regaining effective communication. Gardner and King found that more laxyngectomees with intelligible speech were retained in previous occupations. Specifically, King et al. (1968, p. 200) stated that in his study of veterans,

\footnotetext{
- . half of the eligible patients who were able to communicate by esophageal speech alone had some form of employment, while none of those without esophageal speech were employed.
} 
Data from the present study reveals that $69 \%(N=7 i)$ communicate with esophageal vojce, $12 \%(\mathrm{~N}=12)$ use an artificial larynx, $3 \%(\mathrm{~N}=3)$ rely upon whispering, $0 \%$ gesture without sound, and 16\% $(N=16)$ depend upon writing (See Table III).

\section{TABLE III}

NUNBER AND PERCENTAGE DISTRIBUTION OF PATIENT'S PRESENT COMMUNICATION STATUS

\begin{tabular}{|c|c|c|c|}
\hline Method of Communication & Number & Percentage & $\begin{array}{c}\text { Motal } \\
\text { Number } \\
\text { Responding }\end{array}$ \\
\hline $\begin{array}{l}\text { Artificial Jarynx } \\
\text { Esophageal Speech } \\
\text { Whispering } \\
\text { Gestures } \\
\text { Writing }\end{array}$ & $\begin{array}{r}12 \\
71 \\
3 \\
0 \\
16\end{array}$ & $\begin{array}{r}12 \\
69 \\
3 \\
0 \\
16\end{array}$ & 102 \\
\hline
\end{tabular}

Significantly, results of communicative status found in this sample are closely related to conclusions reported by horr (1962) of a survey of laryngectomees conducted by the ACS. At that time, $54 \%$ spoke entirely with esophageal voice, $10 \%$ spoke extirely with an artificial larynx, and $12 \%$ did not speak at all.

It would appear that communicative ability does affect job retention in the present study since of the $63 \%$ who retumed to work, $66 \%$ used esophageal speech. The remaining 
patients, most of which did not return to work, resorted to non-verbal modes of communication.

3. What Post-Operative Occupational Changes Were Reported?

The subjects' current, post-operative, occupational status is presented in Table IV. Sixty subjects reported

\section{TABIE IV}

NUNBER AND PERCENTAGE DISTRIBUTION OF POST-OPERATIVE OCCUPATIONAI CATEGORIES

\begin{tabular}{|c|c|c|c|}
\hline Category Number and Name & Number & Percentage & $\begin{array}{c}\text { Total } \\
\text { Numbcr } \\
\text { Responcing }\end{array}$ \\
\hline $\begin{array}{l}\text { 1. Professional, Tech- } \\
\text { nical and Nianagerial }\end{array}$ & 5 & 12 & \\
\hline $\begin{array}{l}\text { 2. Clerical and Sales } \\
\text { Occupations }\end{array}$ & 0 & 0 & \\
\hline 3. Service Occupations & 3 & 8 & \\
\hline $\begin{array}{l}\text { 4. Farning, Fishery, } \\
\text { Forestry and Related }\end{array}$ & 0 & 0 & \\
\hline 5. Processing Occupations & 0 & 0 & \\
\hline $\begin{array}{l}\text { 6. Wechinemrades Occupa- } \\
\text { tions }\end{array}$ & 1 & 2 & \\
\hline 7. Bench Work Occupations & 0 & 0 & \\
\hline $\begin{array}{l}\text { 8. Structura]. Work Occupa- } \\
\text { tions }\end{array}$ & 0 & 0 & \\
\hline $\begin{array}{l}\text { 9. Misceilaneous ccoupa- } \\
\text { tions }\end{array}$ & 0 & 0 & \\
\hline 10. Housewife & 2 & 5 & \\
\hline 11. Unemployed & 17 & 17 & \\
\hline 12. Retired & 23 & 56 & \\
\hline & & & 60 \\
\hline
\end{tabular}


post-operative employment (9 were actively employed at the time of the survey, i.e., not retired), while 107 reported pre-operative employment ( 15 were actively employed in categories 1-9, immediately prior to surgery). The twejve occupational categories explained above were utilized for the purpose of analysis and comparison (See Appendix C). In categories number 1-9, based upon the U.S. Department of Iabor, the most significant difference was noted in Category \#9, "Miscellaneous Occupations." These occupations constituted the largest percentage (16\%) pre-operatively, whereas post-operatively $0 \%$ reported to be engaged in these jobs. It may be hypothesized that since these occupations were composed of loggers, railroad laborers, and truck drivers (occupations either involving heavy lifting and/or dusty environments) these patients were perhaps physically unable to continue employment. Other occupational changes occurred in categories \#2 "Clerical and Sales," showing a decrease from $8 \%$ pre-operatively to $0 \%$ post-operatively; \#4 "Trarming, Iishery, and Forestry, etc.," from $4 \%$ to $0 \%$; \#7 "Bench Work, "2\% to 0\%; \#5 "Processing," 3\% to 0\%; \#8 "Structura] Work," from 10\% to 0\%; and \#6 "Machines Trides," decreased from $5 \%$ to $2 \%$. Categories \#1 "Professional, Technical, and Managerial," showed little change (15\% preoperatively and 12\% post-operatively). Number 3 "Service - Docupations" showed small change in status since $7 \%$ of the subjects were engagea in these jobs pre-operatively and $8 \%$ 
post-operatively.

Results of the Horn (1962) study of 3,366 laryngectomees offers some interesing information on occupationai changes or loss of employment following surgery: the greatest job and economic changes, usually in the djrection of a lower income level, occurred in managerial, sales, clerical, skilled-labor, and semi-skilled labor occupations. Professiomal and unskilled-labor occupations reported little change in status. Unfortunately, comparisons of Horn's (1962) results with the present study are limited since a different classification scheme was employed to categorize occupations. It can be speculated, that professional and semi-skilled occupations showed minimal job change in the current study, but generally workers in skilled and unskilled labor were represented by a large decrease in employment following laryngectomy. Interestingly, in the present study, categories represented by a large decrease in employment (numbers $4,5,6,7,8$, and 9) usually involve heavy lifting and dusty-gaseous environments. In categories number 1 and 3 (Professional, etc. and Service Occupations), the physical environments usually are more conducive to adequate stoma breathing. For example, office workers are not normally subjected to adverse environmental conditions and heavy lifting is not a job requirement. These occupations do, however, frequentiy necessitate more verbalization 
and direct contact with the public. Apparently physical environment is more influential in some situations than communication skills as an inaicavor of rememploymeit for zaryngectonees.

A surrey of the remaining three categories revealed no decrease in \#10, "Housewives," whereas in 11 , a change was roted in unemployment figures since the percentages inoreased from $1 \%$ to $1 \%$ pre-operatively to $17 \%$ postoperatively; retirements doubled from $24 \%$ to $56 \%$.

Iorn (1962) also found that the percentage of those who retired doubled fron $12 \%$ before the operation to $24 \%$ soor after, and the percentage of those memployed rose from $2 \%$ before to $8 \%$ following surgery.

To the question, "Was your occupational change as a result of losing your vojee box more favorable ox less farorabie?", 29\% (No=5) of the present subjeots reported more favorable and $71 \%(N=12)$ responded jess favorable (see Tigure 9).

In sum, it would appear that the greatest occupational changes involved an increase in retired and unemployed individuals. Retixement figures were anticipated since the mean age of the sample was 65 years, which is frequently designated as the chronological age of retirement.

4. Was Employment a Primary Motivating Factor in Jeaming Esoohageal Speech? 


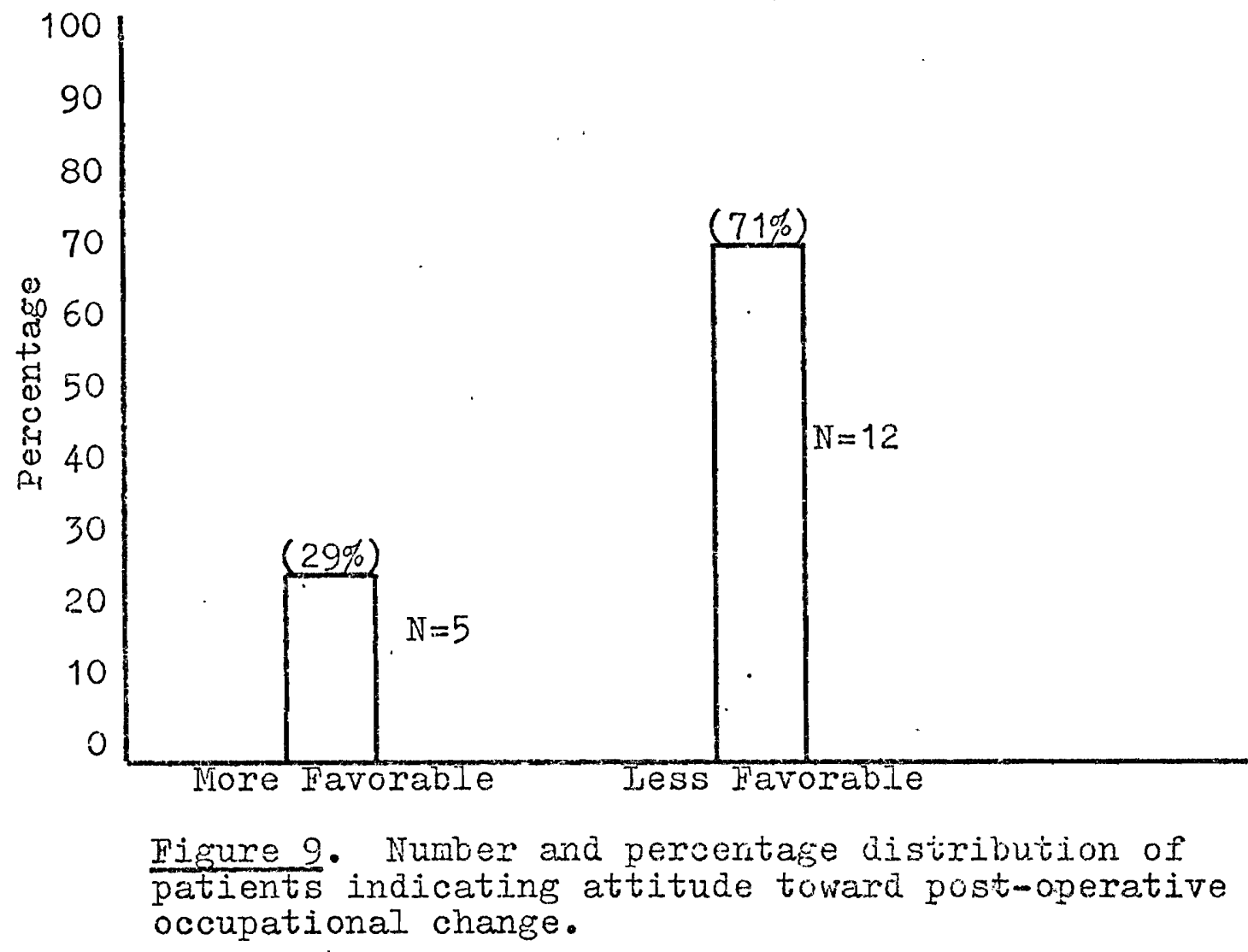

Questionnaire Part II, completed by the spouse, relative, or close friend, involved questions concerning employment, psycho-social adjustment, and attitudes of the spouse and patient. In an effort to obtain data concerning motivat.ing factors in learning esophageal speech, the respondents were requested to indicate which factor motivated this person to learn to speak again.

The largest portion of respondents, $39 \%(N=26)$, replied that "desire to return to work" (See Table V) was the greatest motivating factor in learning to speak; $15 \%(N=10)$ stated desire to communicate at home; $17 \%(N=11)$ was expressed for both a need to communicate socially and visitation by a 


\section{TABIE $V$}

NUMBER AND PERCENTAGE DISTRIBUTION

OF FACTORS MOPIVATING PATIENT

IO LEARN TO SPEAK

\begin{tabular}{|c|c|c|c|}
\hline Factor Option and Title & Number & Percentage & $\begin{array}{c}\text { Total } \\
\text { Number } \\
\text { Responding }\end{array}$ \\
\hline $\begin{array}{l}\text { 1. Desire to return to } \\
\text { work }\end{array}$ & 26 & 39 & \\
\hline $\begin{array}{l}\text { 2. Need to communicate } \\
\text { at home }\end{array}$ & 10 & 15 & \\
\hline $\begin{array}{l}\text { 3. Need to communicate } \\
\text { socially }\end{array}$ & 11 & 17 & \\
\hline $\begin{array}{l}\text { 4. Visitation by a } \\
\text { laryngectomee with } \\
\text { good esophageal } \\
\text { speech }\end{array}$ & 11 & 17 & \\
\hline 5. Other & 8 & 12 & 66 \\
\hline
\end{tabular}

Iaryngectomee; and $12 \%(\mathrm{~N}=8)$ indicated other reasons not 1 isteả. A more specific question involved: "Did employment help to motivate the laryngectomee to learn to speak again?" whe data revealed that of the 39 replies to this question, $87 \%$ $(\mathrm{N}=34)$ answered yes and $13 \%(\mathrm{~N}=5)$ no. Thus, in this population, employment appears to be the most motivating factor encouraging patients to learn esophageal speech.

Snidecoi (1969), Greene (1947), Locke (1966), Schall (1938), Reed (1961), and many others have pointed out that successful training in esophageal speech is, in large part, highly dependent upon the patient's desire to live, recovex, 
and to speak again. "Motivation is without doubt, the most vital factor in the rehabilitation of the laryngectomees" (Iocke, 1966, p. 597). Locke further stated that other factors such as an extroverted personalj.ty, an outlook geared to the future rather than the past, involvement in professional and social activities, all contribute to expedite speech training. Most professionals concerned with rehabilitative management of laryngectomees agree that membership in an IAI affiliated organization offers assistance in helping the patient learn to communicate, while simultaneously providing socializing experiences. In addition, one of the major purposes of IAI Clubs is to assist members in readjusting to previous job routines. Infortunately, this important goal seemed to be fulfilled only to a limited extent in the present study, since of the 40 individuals replying to the question, "Did IAI Club membership help you to readjust to the job routine?" $52 \%(\mathbb{N}=21)$ answered yes and 48\% ( $N=19$ ), no (See Figure 10).

At this point the writer would like to state a subjective opinion concerning the tonality or spirit of the respondents. While reading the laryngectomees replies, the reader is given the impression that the subjects are interested, supportive, and sincerely appreciative of the autrors's concern for the patients. Even though the subjects were not required to identify themselves, more than $75 \%$ signed their names and in many instances persanal 


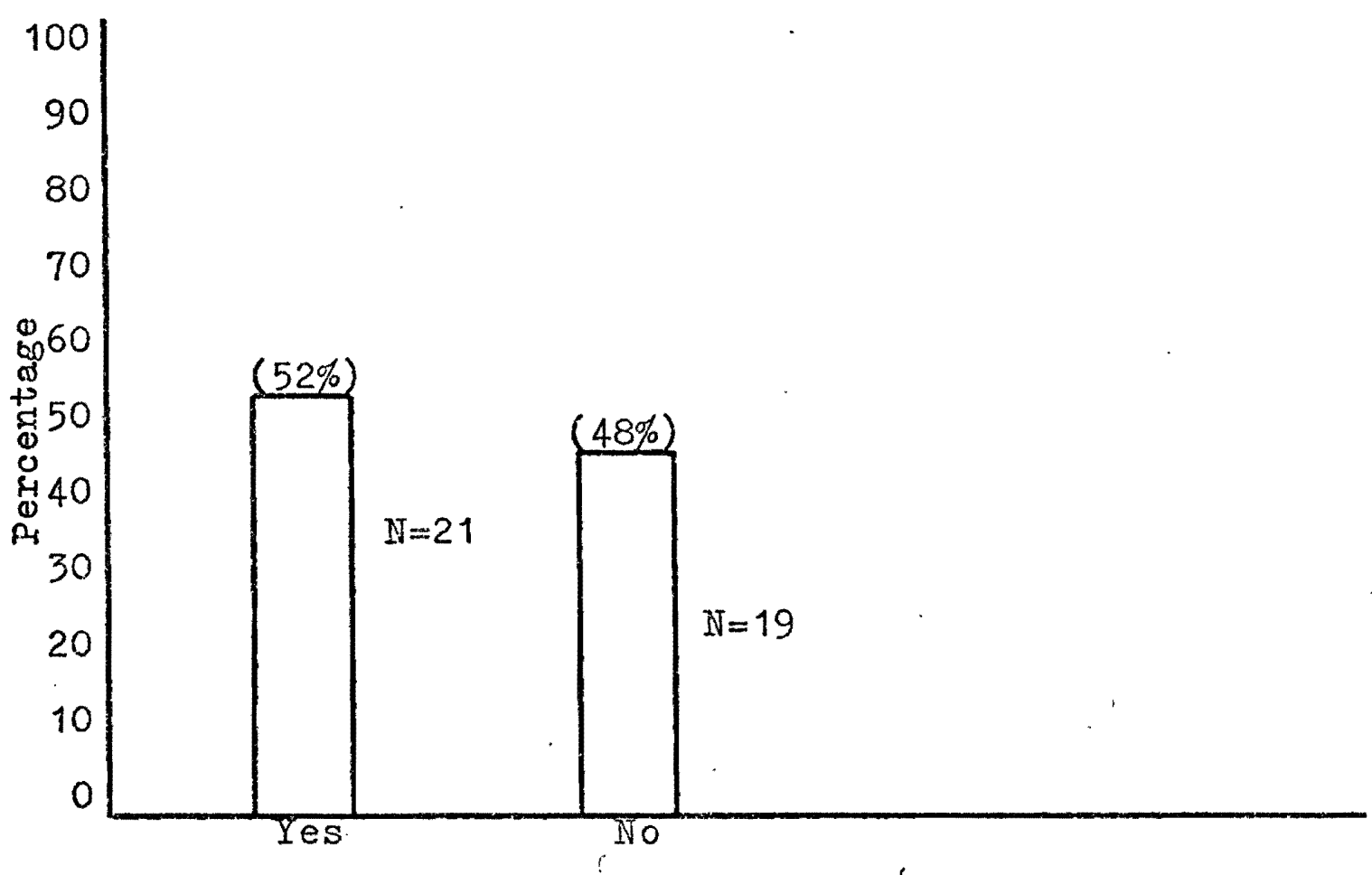

Figure 10. Number and percentage distribution of patients indicating IAI membership helped them return to their job routine.

letters were included expressing appreciation of the survey. Attendance at IAI CIub meetings supports this impression and leads one to conclude that members have pride in their amazing recuperative abilities and this spirit was consequentiy revealed in their responses. It would appear that Locke's description aptly illustrates the present subjects; they are a highly motivated group, interested in the future, and most have attained intelligible speech.

5. Were There Any Financial Changes as a Result of Surgery or Other Consequences on the Famjly of the Iaryngectomized Patient? 
Immediately following surgery the patient may be confronted with the threat of financial catastrophe, especiaiiy those without employment. The American Cancer Society (Horn, 1962) indicated that the average medical and surgical expense of more than 3,000 laryngectomized patients was $\$ 1,700$ but some paid more than $\$ 5,000$. Patients had to borrow money and/or exhaust their savings, and consequently many had no funds remaining for retirement or for learning a new trade. Horn reported that two out of three respondents reported a drop in income following the operation; $60 \%$ attributed the decrease to their laryngectomy and their impaired facility to communicate. Even though no information on current hospital and/or surgical expenses is available, it is estimated that average medical fees and hospital rates have probably doubled or tripled during the last decade. Patients in the present series without medical insurance and/or eligibility for benefits at a government sponsored hospital were possibly faced with stupendous bills.

As a criterion for financial change, the present study posed the question: "Has your average annual income prior to surgery changed as a result of laryngeal surgery?" Of the 86 subjects responding to the question regarding variance in annual income as a result of surgery, 9 (10\%) reported an increase, $27(31 \%)$ a decrease, and a large number, $50(59 \%)$ indicated no change in financial 
stạtus (See Table VI).

TABLE VI

NUMBER AISD PERCENTAGE DISTRIBUTION OF PATIENTS INDICATING VARIANCE IN ANNUAI INCOME FOLIOWING SURGERY

\begin{tabular}{|c|c|c|c|}
\hline $\begin{array}{c}\text { Change in Average } \\
\text { Annual Income }\end{array}$ & Number & Percentage & $\begin{array}{c}\text { Total } \\
\text { Number } \\
\text { Responding }\end{array}$ \\
\hline Increased Annual Income & 9 & 10 & \multirow[b]{5}{*}{86} \\
\hline Decreased Annual Income & 27 & 31 & \\
\hline \multirow{3}{*}{$\begin{array}{l}\text { No Change in Annual } \\
\text { Income }\end{array}$} & 50 & 59 & \\
\hline & & & \\
\hline & 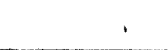 & & \\
\hline
\end{tabular}

Three (3\%) out of 100 subjects wrote that they were assisted by welfare prior to surgery and it would appear that the incidence has not changed since out of 98 respondents only $3(3 \%)$ are currently receiving financial assistance from welfare.

One interesting point that was revealed in this study was response to the question, "What produced the greatest financial stress as a result of surgery?" Options included: cost oI surgery or difficulty speaking. Replies showed that $48 \%(N=31)$ claimed difficult. speaking, $30 \%(N=19)$ cost of surgery, and $22 \%(N=10)$ wrote other answers (i.e. both $6 \%$, none, $15 \%$, and eating 2\%), suggestive that loss of voice is more detrimental than financial strain even though health insurance may have been available (See Figure 11). 


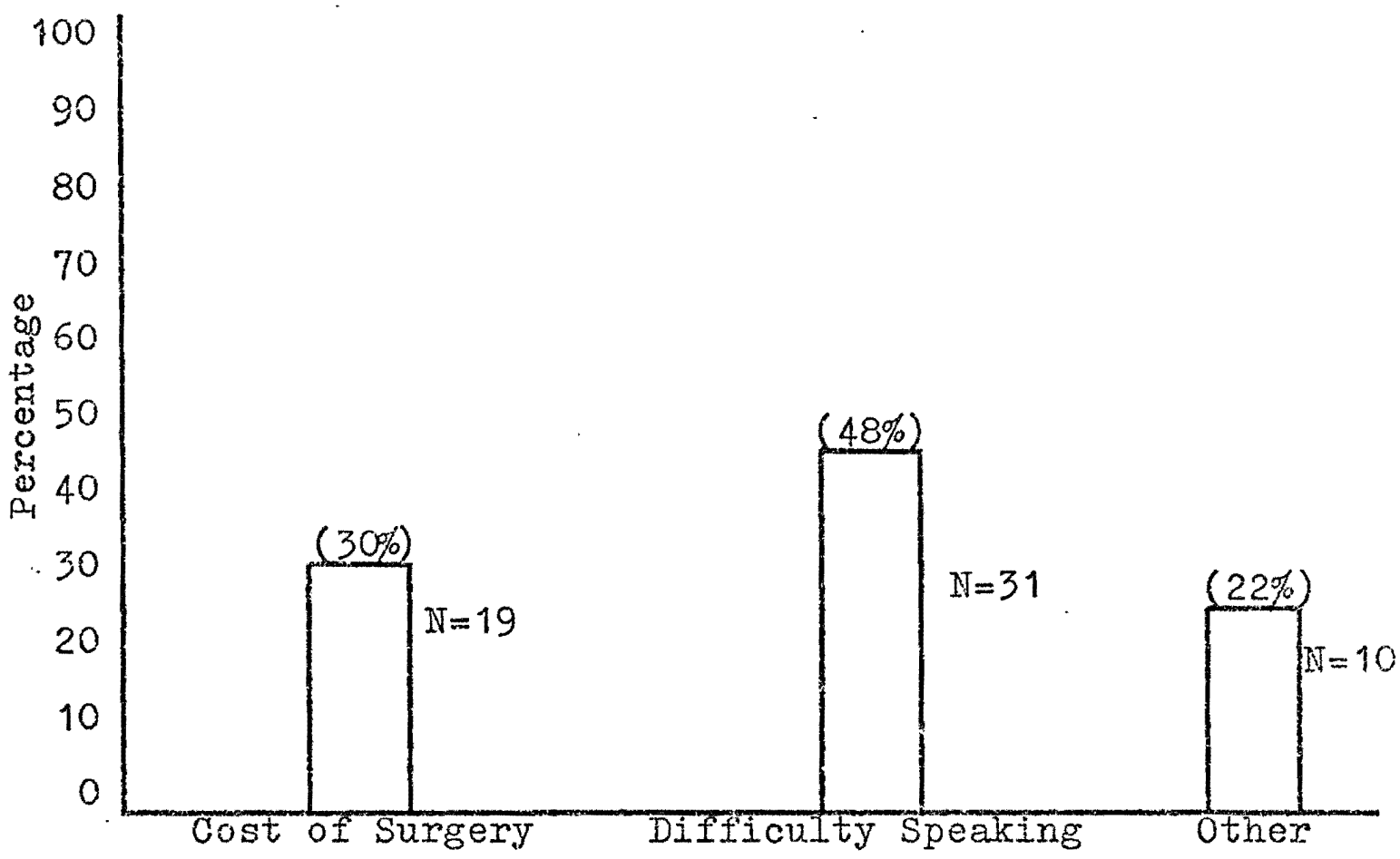

Figure 11. Number and percentage distribution of patients indicatjng which factor produced the greatest financial stress as a result of surgery.

\section{Major Changes in Iife style}

During the second phase of this study (Questionnaire Part II) the respondents were requested to explain the major changes in their lives due to the surgery.

The sixty-one replies received from laryngectomees' spouses were classified according to the following: 1. financial security, 2. marital relations (positive and negative), 3. social changes, 4. psychological stability, and 5. no change. Responses indicate that the largest nuraber, $32(52 \%)$, stated no significant changes were noted; seven (12\%) reported alterations in financial security; $12 \%$ social relations; and $12 \%$ positive marital relations; 
$10 \%$ psychological stability; and six individuals ( $3 \%$ ) felt the major changes involved more negative marital relationships (See Table VII). These figures seem to

TABIE VII

NUNBER AND PERCENTAGE DISTRIBUTIION OF

SPOUSES INDICATING MAJOR CHANGES

OF LIFE STYIE

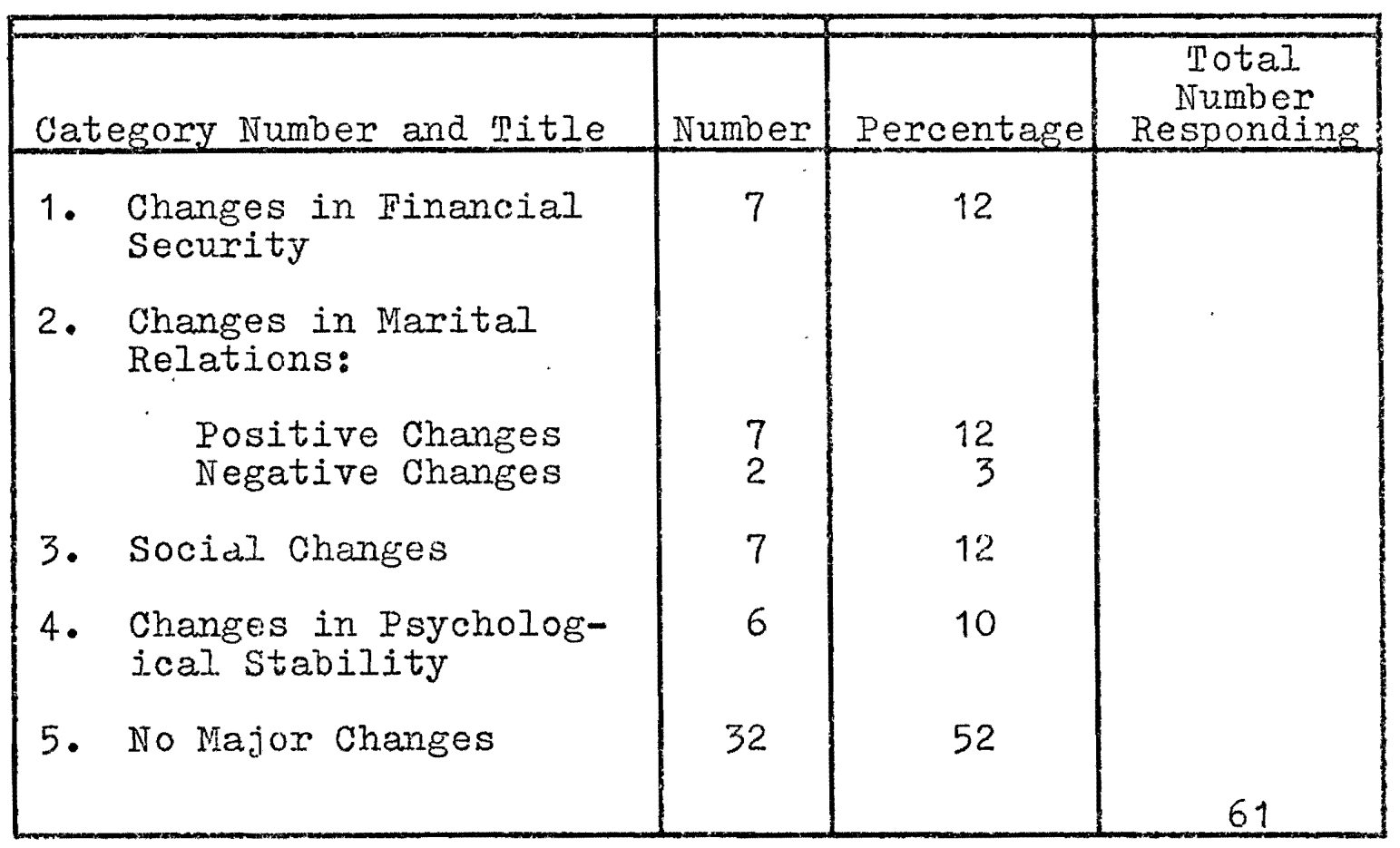

suggest that financial stability does not appear to be the major concern of laxyngectomee's spouses. Representative quotations are cited below:

\section{Financial Security}

"Selling of business and going into mining means we're always away from (our) comfortable home and living in a trailer, though (we) return for brief stays in our home." 
"I have to go to work to support my husband and myself."

"I have had to go to work to supplement our income."

2. Marital Relations (Negative)

Increased tension in the home. Husband 'picks' at wife. Critical of her, rude, embarrasses me in front of relatives and friends. Lack of consideration of others. Due mainly to increased nervousness and lack of ability to provide for wife.

Marital Relations (Positive)

"I love him more."

"It has given us a greater appreciation for each other, family, friends, and our home."

"A closeness at the realization of how nearly I lost him. We found more friends after surgery--real ones--not from pity but admiration of his courage."

3. Social Change

"Not being able to return to life work. Less social activities, more financial worries."

"Not going to group activities or noisy places as it is harder for him to be understood with noise in the background."

"More active in church and club activities."

4. Psychological Stability

"I have to bathe her--ease her crying spells, teach her acceptance of her condition." 
"There are many things that would go unsaid now,

I feel insecure and Ionely at times."

"TCr Ine it's hard to accept his impatience and temper at times."

5. No Change

"No change--he's healthier."

"So far no changes, only for the better." 
CHAPTER IV

SUMMARY AND CONCLUSIONS

Surmary

As emphasized earlier, rehabilitation for laryngectomees should not be restricted to physical recovery, remedial speech training, and psycho-social adjustment, but must be extended to include vocational factors. The results of the present study demonstrate that most laryngectomees in this population are generally well adjusted vocationally and adequately integrated as functioning members of society.

The primary purpose of this study was to examine the pre- and post-operative vocational statis of laryngectomized patients residing in the Northwestern section of the United States. The sample was composed of 210 laryngectomees whose names were supplied by the Oregon Division of the American cancer society. In addition, a restricted population was surveyed consisting of spouses, relatives, or close friends of the patient who chose to participate in the study.

two questionnaires were formulated as a means of collecting aata: Part I was completed by the laryngectomee and Part II by the spouse, relative, or close friend. The 
forms asked a variety of questions involving age, marital status, pre- and post-operative employment, financial status, p:ycho-social adjustment, and method of communication. A total of 117 replies were received from laryngectomees and 76 from spouses or relatives constituting an abundance of information pertaining to the vocational, emotional, and communicative status of Northwest laryngectomees.

Following systematic analysis of the extensive data obtained, five answerable questions were generated restricting the study to a survey of vocational rehabilitation of laryngectomees. Related information concerning manner of communication and psycho-social factors were included in discussions when applicable.

For several reasons, it is not easy to summarize the results of this questionnaire study. The forms were constructed so that as many yes-no check responses as possible could be utilized with additional opportunity for the individual to write out personal comments about the specific area being investigated. Since many of the questions required the patient to recall past experiences, this memory factor can introduce a source of error. The percentages cited are infrequently based upon the total population of responses, since not all. subjects answered each question. Despite these disadvantages, the questionnaires do provide information concerning pre- and postoperative employment status of laryngectomees that would 
have been difficult to obtain in any other manner.

\section{Conclusions}

Significant results of this study are sumarized as follows:

1. The mean age level of the sample was 65 years; it was not surprising that $24 \%$ of the subjects were retired prior to their laryngeal surgery.

2. No specific pre-operative occupational category typified the sample. The largest number of subjects were engaged in miscellaneous occupations such as semi-skilled and unskilled labor.

3. Employment immediately following convalescence was common for the laryngectomees. Results show that of the patients $(N=89)$ returning to their pre-operative occupa tions, $74 \%$ retained the same position and $26 \%$ were retained. by the same company even though they changed positions.

4. The number of retirea laryngectomees doubled following surgery; this finding was anticipated since the mean age level at time of surgery was 65 years which is freguently considered to be an arbitrary retirement age.

5. Desire for employment was shown to be the most motivating factor in learning esophageal speech.

6. It is perhaps significant that many subjects Indjcated dissatisfaction with their post-operative pocationel status. 
7. Esophageal speech is used by a large portion of larryngectomized subjects. This trend appears to be consiscent with results cited by previous studies.

8. While most spouses reported minimal changes in life style following surgery, several indicated marital. problems, financial difficulties and emotional maladjustments.

9. Laryngectoinees projected a spirit of enthusiasm, interest, and sincere appreciation of the authors' investigation.

\section{Implications of the Study}

\section{Rehabilitation}

Statistics indicate that the incidence of laxyngectomy increases steadily each year, and therefore, considerable attention must be directed toward rehabilitative care of these patients. The need for vocational counseling becomes paramount since results of this study show that employment is the most motivating factor in learning esophageal speech.

Even though it is recognized that additional physical problems may influence the patient's re-employability, conciusions from previous studies indicate that the majority of patients are capable of returning to pre-operative employment and/or performing some modified vocational skilis. This evidence together with results of the present study tend to support the need for rocational counseling 
following surgery.

In addition to providing esophageal speech training and encouraging social activities, a major goal of IAI Clubs is to promote vocational readjustment, thus, surgeons and speech pathologists should recommend that patients seek membership in local chapters. Another source of vocational assistance is provided by the Division of Vocational Rehabilitation. Most large cities have access to vocational. courselors through DVR so that if occupational change is varranted these counselors can provide necessary guidance and training.

Some subjects in the present study indicated dissatisfaction with post-operative vocational status either with reference to retirement and/or loss of previous employment. In these cases, the services of a trained vocational counselor appears to be vitally important in order to aid these patients in achieving maximum total rehabilitation.

Speech pathologists concerned with remedial speech training should recognize that return to work was considered to be the most motivating factor in learning esophageal speech by the majority of subjects in the present sample who desired employment. Thus, some form of post-operative employment should be encouraged whenever feasible since vocational readjustment appears to significantly influence successful rehabilitation of laryngectomized patients. 
Need for Future Kesearch

1. It is suggested for future studies of this nature trat the age level of laryngectomees be controlled so that the subjects are less than 65 years of age.

2. An interesting investigation might involve a survey of laryngectomees who did and did not receive vocational guidance following surgery comparing job satisfaction, employer satisfaction, esophageal speech skill, etc.

3. Questions concerning how long the patient was employed following surgery and did attitudes change with increasing time, require further examination.

4. Another study might survey employer's reaction to the question: "Does communication loss affect job retention?" 


\section{BIBLIOGRAPHY}

\section{References}

American Cancer Society and International Association of Laryngectomees. "Laryngectomees at Work," No. 4519, $(1966)$.

Baker, E. Ro, and J. Cherry. "Carcinoma of The Larynx: Results of Therapy in 209 Cases," Arch. Surg., 90 $(1965), 449-453$.

Boone, Daniel R. The Voice and Voice Therapy (New Jersey:

Creech, Henry B. "Evaluating Esophageal Speech," Journal of the Speech and Hearing Association of Virginia, $7,(1966), 13-19$.

Diedrich, William M., and K. A. Youngstrom. Alaryngeal Speech (Springsfield: Charles C. Thomas, 1966).

Gardner, Warren H. "Problems of Laryngectomes," Rehabilitation Record, $3(1961), 15$.

Gardner, Warren H. "Laryngectomees (Neck Breathers) In Industry," 9 (1964), 777-789.

Gardner, Warren H. "Adjustment Froblems of Laryngectomized Women," Archives of Otolaryngology, 83 (1966), 31-42.

Greene, J. S. "Isaryngectomy and its Psychologic Implications," New York Journal of Medical, 47:53-56, $(1947)$.

Harrington, R. "Problems Associated with the Development of Pseudo-Voice in the Aged Laryngectomee," ASHA Convention Report, 1960.

Heaver, I., and G. E. Arnold. "Rehabilitation of Alaryngeal Aphonia," Postgrad. Med. 32: (1962), 11-17.

Holinger, P. H., K. C. Johnston, and M. D. Mansueto. "Cancer of the Larynx," The American Journal of Nursing, 57 (1957), 738-41. 
Horn, D. "Laryngectomees: Survey Report," International Association of Iaryngectomees News, VII (1962), 1 .

Hunt, Brooks, R. "Rehabilitation of the Laryngectomee," Laryngoscope, 74: (1964), 382-393.

Jackson, C. I., and C. M. Norris. "Cancer of the Larynx, Part II, Incidence and Etiology-Pathology and Classification," Cancer, 12 (1962), 56-62.

Jimison, C. "Nursing the Patient After Laryngectomy," American Journal of Nursing, IVII (1957), 741-43.

King, Phjlip S., E. V. Foulks, and G. A. Peirson. "Rehabilitation and Adaptation of Laryngectomy Patients," American Journal of Physical Medicine, 47 (1968), 192-202.

King, Philip S. Personal Communication, (1970).

Ievin, Nathaniel M. "Iaryngectomy," Rehabilitation Record, 7 (1966), 13.

Jocke, Bernard. "Psychology of the Laryngectomy, "Military Medicine, 131 (1966), 593-599.

Martin, H. "Speech Rehabilitation Following Laryngectomy; general consideration," Talk, 36 (1955), 4-6.

Moolenaar-BIJI, A. "The Importance of Certain Consonants in Esophageal Voice After Laryngectomy, "Annals of otology, Rhinology, and Laryngology, LXII (1953), 979089.

Murphy, G. E., A. I. Bisno, and H. A. Ogura. "Determinants of Rehabilitation Following Laryngectomy, "Laxyngoscope, 74 (1964), 1534-1549.

Nahum, Alan M., and J. S. Golden. "Psychological Problems of Laryngectomees," Journal of American Medical Association, 186 (1963): 1136-38.

Pitkin, Y.N. "Factors Affecting Psychologic Adjustment in the Laryngectomized Patient," Arch. Otolary., 58 (1953), 38-49.

Ranney, Jack I. "One Out of Five Ioses Job After Voice Operation," IAI News, 10 (1965), 1 .

Reed, G. F. "The Iong Term Follow-Up Care of Laryngectomized Patients," Journal of the American Medical Association, $175(1961), 132-36$. 
Schall, I. A. "Psychology of Laryngectomized Patients," Archives of otolaryngology, 28 (1938), 581-584.

Snidecor, John C., and Others. Speech Rehabilitation of the Iaryngectomized (IIlinois: Charles C. Thomas, 1969).

Stoll, Bernard. "Psychological Factors Determining the Success and Failure of the Rehabilitation Program of Laryngectomized Patients," Annals of Otology, Rhinology, and Laryngology, 67 (1958), 550-56.

Waldrop, W. F., and M. A. Gould. Your New Voice (Illinois: American Cancer Society, 1956).

Wirtz, W. Willard. Dictionary of Occupational Titles: Definitions and Titles, U.S. Department of Labor $(1965)$. 
APPENDIX A

COVER IIETTER

QUESTIONNAIRE PART I

QUESTIONNAIRE PART II 


\section{Portland State University}

P.O. Box 757

Department of Speech

Program in Speech \& Hearing Sciences

August 10,1970
Portland, Ore. 97207

$503 / 226-7271$

Dear

I would appreciate your help as a laryngectomee in filling out the encloscd questionnaires. The purpose of this necessary information from you is actually three fold: (1) to help new fellow laryngectomees and their families with personal adjustments; (2) to assist employed larymgectomees and their employers in better understanding some of the problems associated with this surgery; (3) to aid individuals who are assisting laryngectomees, hoth with speech and with job placement, toward $a$ better understanding.

This survey does not require you to indicate your name or address unless you desire to do so. What we are interested in is your honest opinions concerning the items on the questionnaires. It is imnortant that these forms be filled out as soon as possible. If you have any questions concerning this research, please call Mrs. Susan leonti at 774-8188, or Dr. James F. Maurer, 229-3554.

All information that you provide on the enclosed questionnaires will be strictly confidential. This research is being coordinated through the Oregon Division of the American Cancer Socicty, the Veterans Administration Hospital, and the New Voice Club of the Northwest. Your assistance. in completing the enclosed forms will be of great benefit to this study.

Sincerely yours,

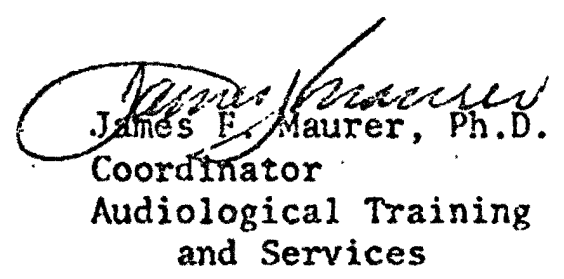




\section{QUESTIUNNAIRE PART I}

1. Name and address of physician who performed your surgery:

2. Please circle your current age group:
$21-30$
$31-40$
$41-50$
$51-60$
$61-70$
$71-80$

3. Sex: Female Male

4. Occupation prior to your laryngeal problems: Length of time employed:

5. Did you return to your previous occupation after surgery? yes no (Please circle appropriate answer)

If you answered "yes," to number 5 please complete the following:

a. Do you hold the same position? yes no

b. Does your position require the use of speech? yes no

c. Are you required to deal with the public? yes no

d. Did you notice a change in your employer's attitude toward you after surgery? more favorable? less favorable? no change?

e. Did you notice a change in your attitude toward your 
job after surgery? more favorable? less favorable? no change?

If you answered "no," to number 5 please complete the

following:

a. Please explain why you did not return to your previous occupation:

b. Was it your own decision or your employer's not to return to your previous job? my decision employer's decision both

c. What is your present occupation?

d. Was your occupational change as a result of losing your voice box? more favorable? less favorable?

6. Is speaking necessary in your present occupation? always usually sometimes seldom never

What situations necessitate use of speech? (e.g. frequent use of telephone)

7. What produces the greatest emotional stress? attitudes of employer attitudes of fellow workers

8. Did you receive financial assistance from welfare prior to surgery? yes no Are you currently receiving financial assistance from welfare? yes no 
Has your average annual income prior to surgery changed as a result of laryngeal surgery? increased decreased no change

Are you currently receiving financial benefits from social security, a pension, or etc.? yes no If you answered "yes," please explain:

What has produced the greatest financial stress as a result of surgery? cost of surgery? difficulty speaking?

9. Are you a member of an IAL* affiliated club? yes no If you answered "yes," do you feel that this membership helped you to readjust to the job routine? yes no

10. What is your usual method of communication? (Please circle only one)

artificial larynx

esophageal speech

whispering

gestures without sound writing

11. Circle approximate percentage of time spent speaking on your job: $100 \% \quad 80-99 \% \quad 60-79 \% \quad 40-59 \% \quad 20-39 \%$ $11-19 \%$ less than $10 \%$

12. Do you work in a noisy environment (e.g. factory, shop, etc.)? yes no

*International Association of Laryngectomees 
Do you work in an environment exposed to dusts, gaseous fumes, too much heat or humidity, etc.? yes no

13. Do you feel that your employer has been adequately informed of the nature and problems of the laryngectomized? yes no

14. Please rate the condition of your speech:

Circle the word or numbers that best describes your speech in the following sentences:

a. My speaking volume is loud enough to be heard at a distance of 10 feet. always most of the time sometimes seldom never b. My speech is understood by others: always most of the time sometimes seldom never c. My maximum number of words per air charge is: $\begin{array}{llllll}0-1 & 2-3 & 4-5 & 6-7 & 8-9 & \text { over } 10\end{array}$

d. I communicate comfortably with fellow workers and the general public:

always most of the time sometimes seldom never e. I am able to speak distinctly on the telephone: always most of the time sometimes seldom never

15. Have you had formal speech instruction other than that provided by an IAI Club? (e.g. by a Speech Therapist) yes no where?

16. Do you now spend less time speaking than you did prior 
to surgery? yes no

17. Do you presently communicate as freely with the following as you did prior to your surgery?

strangers in the office yes no

strangers on the telephone yes no

employer yes no

fellow workers yes no

relatives yes no

friends yes no

family members yes no

18. Please check highest level of education completed:

elementary school and below

high school training

high school graduate

vocational training ( $P$ lease describe:

college training

college graduate

graduate work

19. Did you need additional vocational training as a result of your surgery? yes no

20. Have you noticed any marital stress following your laxyngectomy? yes no

If so, check categories most appropriate:

separation from spouse

divorce

alienation from family 
increased family stress

21. Do you find that you are less active in social functions since your surgery? yes no (If "yes," please check appropriate categories)

discontinued club activities

discontinued church activities

less entertaining of friends in your home

fewer invitations from friends

less entertainment away from home

(movies, dinner dates, etc.)

less traveling

Thank you for completing this questionnaire. This information will help future laryngectomees. Your assistance is appreciated. 
TO BE COMPLEPED BY CLOSE FAMILY MEMBER OR SOME PERSON IIVING WITH YOU

(If you live alone please mark an $X$ here __ and return this
form.)

1. What is your relationship to the laryngectomee?

2. Do you presently live with the laryngectomee? yes no

3. Did you live with the laryngectomee prior to her/his laryngeal problems? yes no

4. Please circle the word that best describes this patient's initial reaction to the diagnosis of cancer: shock acceptance denial (refusal to believe diagnosis) panic (fear) other

5. Please circle the number of the phrase that best describes this patient's reaction to the knowledge that her/his voice box would be removed:

1. Acceptance of the realization that she/he would have to learn a new methor of speaking.

2. Despair of any hope of regaining speech.

3. Discouragement to the point of no desire to ever speak again?

4. Other 
6. Which of the following motivated this person to learn to speak again? (Please circle only one)

1. Desire to return to work.

2. Need to communicate at home.

3. Need to communicate socially.

4. Visitation by a laryngectomee with good speech after surgery.

5. Other

7. Please explain how you reacted to the diagnosis of cancer:

8. Did you attend pre-operative counseling sessions with the laryngectomee? yes no (If you answered "yes," where:

Did another laryngectomee visit this patient before and/or after surgery? yes no

9. Did you attend speech instruction classes with the laryngectomee after surgery? yes no

10. How did you react to the knowledge that the patient's speech would be different after surgery?

11. Did you have a difficult time accepting the laryngectomee's new form of speech after surgery? yes no

12. Which of the following emotional problems characterized this patient's behavior immediately following surgery? (Please circle the appropriate numbers) 
1. Depression

2. Disinterest in the world around him/her

3. Neglect of personal grooming

4. Social withdrawal

5. Crying spells

6. Feelings of hopelessness

7. Desire for death

Did any of these feelings exist prior to surgery?

Please write the numbers of the above appropriate

behaviors which existed prior to surgery

Which of these feelings still exist today? Please write the numbers of the above appropriate behaviors which still exist today

13. How does the laryngectomee usually communicate? (Please circle only one)

Artificial larynx

Esophageal speech

Whispering

Gestures without sound Writing

14. Do you presently feel comfortable communicating with the laryngectomee? yes no If you answered "no," please explain

15. What percentage of the time do you spend speaking for the laryngectomee?

$0 \% \quad 10-20 \% \quad 30-4.0 \% \quad 50-60 \% \quad 70-80 \% \quad 90-100 \%$ 
16. Do you treat the laryngectomee differently now than you did before surgery? yes no If "yes," please explain:

17. Is the laryngectomee presently employed? yes no If you answered "yes," to number 17 please complete the following:

a. Do you feel that employment helped this patient to reaỏjust socially after surgery? yes no

b. Did employment help to motivate the laryngectomee to learn to speak again? yes no

c. Does this laryngectomee have the same attitudes toward her/his job as before surgery? yes no

18. Please complete the following if you are the husband or wife of the laringectomee:

a. Have your marital relations changed since surgery? yes no If you answered "yes," please explain:

b. Do you and your husband/wife presently spend less time entertaining friends in your home than you did before surgery? yes no

c. Do you and your spouse presently spend less time visiting friends than you did before surgery? yes no

d. Are you and your spouse now less active in club and church activities? yes no

e. Is your spouse more dependent upon you now as 
compared to how he/she was before surgery? yes no

f. Do you and your spouse now spend less time communicating with each other? yes no

g. Does your spouse treat the children differently since surgery? yes no

h. Does your spouse have less patience than he/she did before surgery? yes no

i. Please explain the major changes in your life due to the surgery:

Thank you for completing this questionnaire. This information will help future laryngectomees. Your assistance is appreciated. 
A PENDIX B

IIST OF PRE-OPERATIVE JOBS 
CATEGORY 1: PROFESSIONAI, TECHNICAI, AND MANAGERIAL

Job Title Provided by Subject

Total Total

Accountant

Postmaster

Teacher of Private Music Lessons

Engineer

Supervisor

Factory Supervisor

Manager, Fruel Oil Company

Purchasing Manager

U.S. Immigration Officer

Engineer in Theatre

U.S. Civil Service

Insurance Loss Prevention Examiner

Coder for Computor

Electronic Engineer

Highway Construction Supervisor

V.P. Rubber Manager

Number Percentage

CATEGORY 2: CLERICAL AND SAIES OCCUPATIONS

Shoe Salesman

Bookkeeper

Salesman

Sales Manager

Car Salesman

Medical Steno

Sales and Distribution of Farm and

Chemical Supplies

Wholesale Auto Parts Salesman

Paymaster

CATEGORY 3: SERVICE OCCUPATIONS

Cook

Waitress

Waitress

Bartender

Operator of Pro Shop

Waitress, Bartender, Cook

Tavern Owner

Bartender 
CATEGORY 4: FARMING, FISHERY, FORESTRY, AND RELATED OCCUPATIONS

Job Title Provided by Subject

Total Total Number Percentage

Landscaper

Farm Work

Farmer

Farmer-Stockman

4

$4 \%$

CATEGORY 5: PROCESSING OCCUPATIONS

Hard Board Plant Operator

Mill Edgerman

Mill Worker

CATEGORY 6: MACHINES-TRADES OCCUPATIONS

Hydro-electro Operator

Assistant Water Driliing Forman

Machinist

Machinist and Millwright

Fireman Saw Mill

5

$5 \%$

CATEGORY 7: BENCH WORK OCCUPATIONS

Dental Lab Worker

Dental Lab Worker

2

$2 \%$

CATEGORY 8: STRUCTURAI WORK OCCUPATIONS

Cement Contractor

Electrical Mechanic

Carpenter

Structural Iron Worker

Mineral Sands Worker

Dock Super

Steamfitter

Carpenter

Carpenter

Construction Millwright

Construction Welder 
GATEGORY 9:- MISCELIANEOUS

Job Title Provided by Subject

Total Total Number Percentage

Truck Driver

Logging Engineer

Bus Driver

Logger (Cutting Crew)

Whistle Punk

Cat Driver

Truck Driver

Iumber Tallyman

Locomotive Engineer

Logging (Self-employed)

Truck Driver

Truck Driver

Railroad Laborer

Forman Switch Engine

Iongshoreman

Auto Business

CATEGORY 10: HOUSEWIFE

CATEGORY 11: UNEMPLOYED

$1 \quad 0.9 \%$

CATEGORY 12: RETIRED

26

$24 \%$

Categories 1-9 were designated by the U.S. Department of Iabor in the Dictionary of Occupational Titles: Defiritions and Titles, W. Willard Wirtz, (ed.), 1965. Categories 10-12 were inserted for purposes of this study. 
APPENDIX C

\section{IIST OF POST-OPERATIVE JOBS}


CATEGORY 1: PROFESSIONAL, TECHNICAI, AND MANAGERIAI,

Job Title Provided by Subject

Total Total

Teacher of Esophageal Speech

Number Percentage

Communication Consultant

Office Manager

Construction Inspector

Head of Pricing Department

5

$12 \%$

CATEGORY 2: CIERICAI AND SALES OCCUPATIONS

0

$0 \%$

CATEGORY 3: SERVICE OCCUPATIONS

Janitor

Camp Manager and Caretaker

Janitor

3

$8 \%$

CATEGORY 4: FARMING, FISHERY, FORESTRY, AND RELATED OCCUPATIONS

0

$0 \%$

CATEGORY 5: PROCESSING OCCUPATIONS

$0 \quad 0 \%$

CATEGORY 6: MACHINES-TRADES OCCUPATIONS

Iube and Tireman

1

$2 \%$

CATEGORY 7: BENCH WORK OCCUPATIONS

0

$0 \%$

CATEGORY 8: STRUCTURAI WORK OCCUPATIONS

0

$0 \%$

CATEGORY 9: MISCELTANEOUS

0

$0 \%$ 
CATEGORY 10: HOUSEWIFE

Job Title Provided by Subject

Total Total

Housewife and Homemaker

Number Percentage

2

$5 \%$

CATEGORY 11: UNEEMPLOYED

$7 \quad 17 \%$

CATEGORY 12: RETIRED 


\section{Pypist:}

Karen Stover 